\title{
Profiling the cell walls of seagrasses from A (Amphibolis) to Z (Zostera)
}

\author{
Lukas Pfeifer ${ }^{1}$, Gijs van Erven², Elizabeth A. Sinclair ${ }^{3}$, Carlos M. Duarte ${ }^{4}$, Mirjam A. Kabel ${ }^{2}$ and Birgit Classen ${ }^{*}$
}

\begin{abstract}
Background: The polyphyletic group of seagrasses shows an evolutionary history from early monocotyledonous land plants to the marine environment. Seagrasses form important coastal ecosystems worldwide and large amounts of seagrass detritus washed on beaches might also be valuable bioeconomical resources. Despite this importance and potential, little is known about adaptation of these angiosperms to the marine environment and their cell walls.

Results: We investigated polysaccharide composition of nine seagrass species from the Mediterranean, Red Sea and eastern Indian Ocean. Sequential extraction revealed a similar seagrass cell wall polysaccharide composition to terrestrial angiosperms: arabinogalactans, pectins and different hemicelluloses, especially xylans and/or xyloglucans. However, the pectic fractions were characterized by the monosaccharide apiose, suggesting unusual apiogalacturonans are a common feature of seagrass cell walls. Detailed analyses of four representative species identified differences between organs and species in their constituent monosaccharide composition and lignin content and structure. Rhizomes were richer in glucosyl units compared to leaves and roots. Enhalus had high apiosyl and arabinosyl abundance, while two Australian species of Amphibolis and Posidonia, were characterized by high amounts of xylosyl residues. Interestingly, the latter two species contained appreciable amounts of lignin, especially in roots and rhizomes whereas Zostera and Enhalus were lignin-free. Lignin structure in Amphibolis was characterized by a higher syringyl content compared to that of Posidonia.
\end{abstract}

Conclusions: Our investigations give a first comprehensive overview on cell wall composition across seagrass families, which will help understanding adaptation to a marine environment in the evolutionary context and evaluating the potential of seagrass in biorefinery incentives.

Keywords: Seagrass, Cell wall, Polysaccharide, Lignin, Apiogalacturonan, Pyrolysis, Gas chromatography

\section{Background}

Seagrasses are an evolutionary unique, polyphyletic group of angiosperm plants, which evolved early in the evolution of monocotyledonous plants, and colonized the sea more than 100 million years ago [1]. This adaptation to the marine environment was performed in three to four independent lineages [2], which gave rise

\footnotetext{
*Correspondence: bclassen@pharmazie.uni-kiel.de

${ }^{1}$ Pharmaceutical Institute, Department of Pharmaceutical Biology, Christian-Albrechts-University of Kiel, Gutenbergstr. 76, 24118 Kiel, Germany

Full list of author information is available at the end of the article
}

to the four major seagrass families. Strikingly, despite their independent evolutionary routes, seagrasses from the different lineages have evolved many morphological similarities, which indicates that the marine surrounding imposes selection forces that can lead to convergent evolution [3]. All seagrasses belong to the order Alismatales and comprise around 70 species within these families (Posidoniaceae, Zosteraceae, Hydrocharitaceae, and Cymodoceaceae). The Posidoniaceae are monogeneric, the Zosteraceae consist of four genera (Heterozostera, Phyllospadix, Nanozostera and Zostera), the Hydrocharitaceae include some freshwater and three marine (Enhalus, Halophila, and Thalassia) genera and

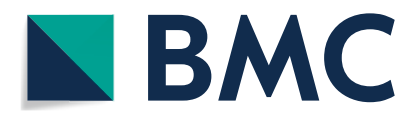

(c) The Author(s) 2022. Open Access This article is licensed under a Creative Commons Attribution 4.0 International License, which permits use, sharing, adaptation, distribution and reproduction in any medium or format, as long as you give appropriate credit to the original author(s) and the source, provide a link to the Creative Commons licence, and indicate if changes were made. The images or other third party material in this article are included in the article's Creative Commons licence, unless indicated otherwise in a credit line to the material. If material is not included in the article's Creative Commons licence and your intended use is not permitted by statutory regulation or exceeds the permitted use, you will need to obtain permission directly from the copyright holder. To view a copy of this licence, visit http://creativecommons.org/licenses/by/4.0/. The Creative Commons Public Domain Dedication waiver (http://creativeco mmons.org/publicdomain/zero/1.0/) applies to the data made available in this article, unless otherwise stated in a credit line to the data. 
the Cymodoceaceae exhibit the highest variety of genera (Amphibolis, Cymodocea, Halodule, Syringodium and Thalassodendron) [1]. The genus Ruppia, which occurs in brackish water, is sometimes classified in the Cymodoceaceae [4], but the Angiosperm Phylogeny Group IV System [5] uses the traditional assignment to Ruppiaceae. Species of Ruppia are not restricted to marine waters and show a high variability in accepted salinity gradients [6-8]. They are not always accepted as seagrasses sensu stricto, but are included in our research because of their ecological similarity to seagrasses.

Seagrasses form important, highly productive coastal ecosystems worldwide (except Antarctica) and aid the stabilisation of sediments. Together with macroalgae, seagrasses are the dominant primary producers in coastal waters. They provide structural habitat and feeding grounds for diverse and abundant biological communities, including threatened organisms like dugongs, turtles and sea horses [9-11]. Despite their vital role, human pressures have led to significant declines of seagrass meadows, prompting the need for protection and restoration. Furthermore, large amounts of seagrass litter is washed onto beaches. Seagrasses could, therefore, form an interesting alternative feedstock for utilization in a biobased economy, not competing for arable land, that could support production of biofuels and chemicals [12].

The existing literature on adaptation of these angiosperms to the marine environment is surprisingly limited, despite the ecological importance of seagrass species. Genome sequencing of two Zostera species suggested that adaptation to the marine habitat was accompanied by a reduction in gene numbers of some genes involved in cell wall recycling and modification in comparison to Arabidopsis and Oryza [13, 14], though actual cell wall compositional analysis was not performed. In fact, very little is known about the cell wall composition and architecture of seagrasses (for review see [15]). Cellulose (e.g. [16]) and hemicelluloses (e.g. [17]) are considered the main components of cell walls in terrestrial and marine plants, although detailed studies on characterization of distinct (hemicellulosic) polysaccharide structures/ populations are missing. Unique structural features were identified in some seagrass species and include sulfated polysaccharides rich in galactosyl (Gal) units [18-20] and unusual pectic polysaccharides mainly composed of galacturonyl (GalA) and apiosyl (Api) units (apiogalacturonans, [21]).

The secondary walls of vascular terrestrial plants also contain the cross-linked aromatic polymer lignin. Lignin is formed by radical coupling of the $p$-hydroxycinnamyl alcohols $p$-coumaryl alcohol, coniferyl alcohol and sinapyl alcohol which, respectively, give rise to $p$-hydroxyphenyl $(\mathrm{H})$, guaiacyl (G) and syringyl (S) units, when incorporated into the lignin polymer [22]. The composition and structure of the lignin population depends largely on the botanical origin, but also varies substantially within plant species, e.g. as an effect of age or tissue/organ type [22, 23].

Lignin covalently and non-covalently interacts with the cell wall polysaccharides and thereby plays a pivotal role in mechanically strengthening of plant cell walls [24]. However, the question of whether seagrass cell walls contain lignin is still under debate [25-28]. One of the reasons for this discussion is that methodologies to quantify and qualify lignin polymers have been based on non-specific and non-sensitive gravimetric analysis [29, 30]. The presence of lignin was detected in some seagrass species by more detailed analysis using pyrolysis gas chromatography mass spectrometry (pyrolysis-GC-MS) [29, 31-33]. This technique allows for specific lignin quantification and structural characterization by employing uniformly ${ }^{13} \mathrm{C}$ labelled lignin internal standards $\left({ }^{13} \mathrm{C}-\mathrm{IS}\right)$, opening up new possibilities to map the presence of seagrass lignin in more detail $[34,35]$. Detailed NMR analyses of cell walls in Posidonia australis and Posidonia oceanica showed that sheath tissue of the latter species contained a unique, heavily $p$-hydroxybenzoylated lignin structure [36, 37]. This feature might relate to the seagrasses' habitat, and could provide an untapped resource of novel biobased aromatics.

Incorporation of lignin into the cell wall as a common feature among seagrass families, however, is not yet confirmed. Likewise, the question whether some commonality exists in the cell wall polysaccharide composition, architecture and organisation among seagrass families remains unanswered. Here, we investigated the cell walls of seagrasses by examination of the polysaccharide composition and lignin content and structure across different families and locations. We analyzed nine species sampled from the Baltic Sea (Ruppia spp., Ruppiaceae; Zostera marina and Zostera noltii, Zosteraceae), the Mediterranean Sea (Cymodocea nodosa, Cymodoceaceae), the Red Sea (Enhalus acoroides and Thalassia hemprichii, Hydrocharitaceae) and the Indian Ocean (P. australis and Posidonia sinuosa, Posidoniaceae and Amphibolis antarctica, Cymodoceaceae) (Fig. 1, detailed information in Table S1). The studied species cover the four seagrass families, including the brackish water family of Ruppiaceae, as well as the three groups of seagrasses which are regarded to have evolved independently [2].

\section{Results}

Sequential extraction of polysaccharide fractions

from nine seagrass species

Comparison of the constituent carbohydrate composition of the different fractions

A sequential extraction with solvents specific for different polysaccharide classes [38, 39] was performed. An 


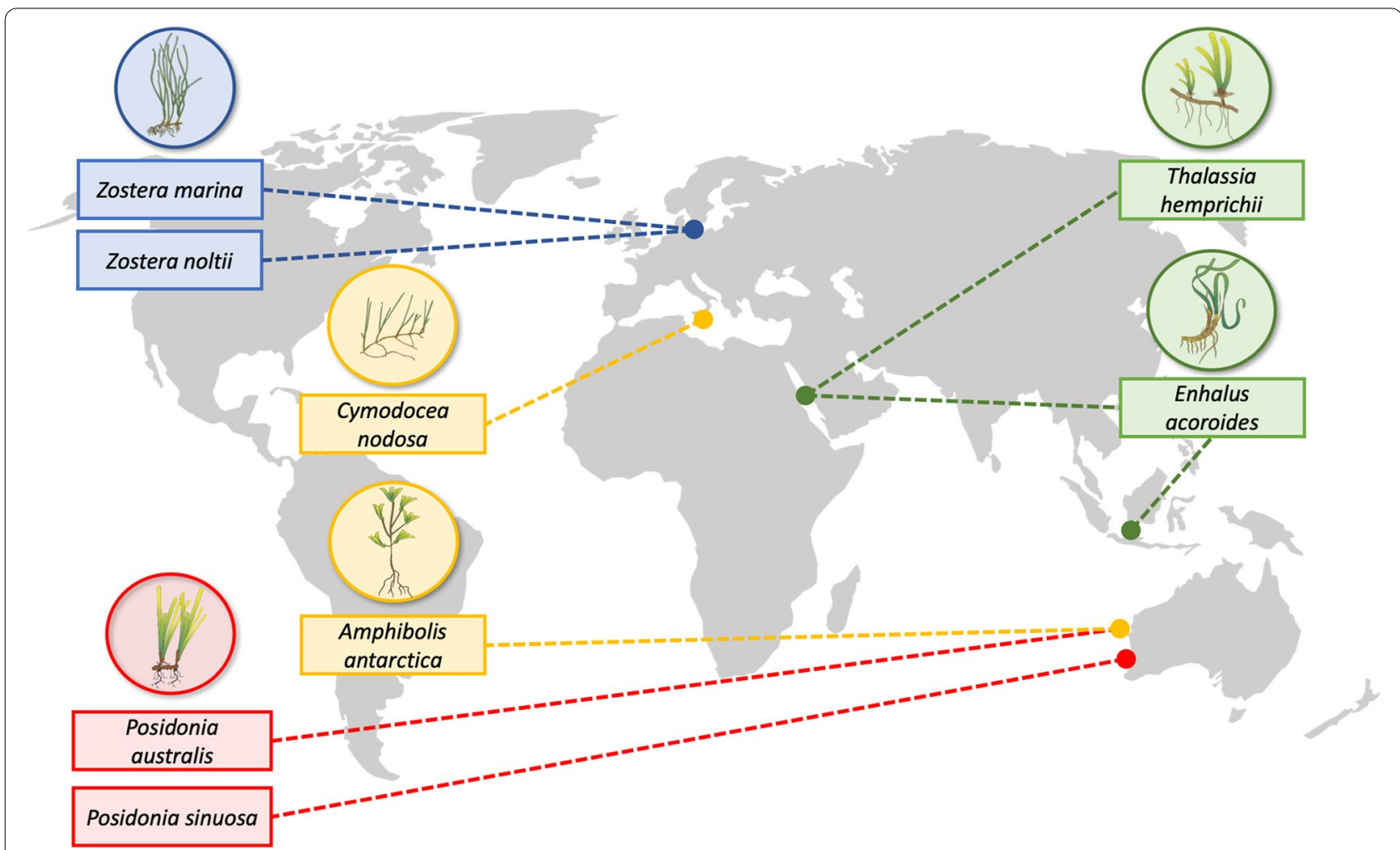

Fig. 1 Sampling location of seagrass species investigated in this study. Families: blue: Zosteraceae; green: Hydrocharitaceae; yellow: Cymodoceaceae; red: Posidoniaceae. Plant vector symbols were used from Catherine Collier (James Cook University) and Tracey Saxby (Integration and Application Network) from the webpage https://ian.umces.edu/media-library under the license CC BY-SA 4.0 and integrated in this figure (distributed under the same license; https://creativecommons.org/licenses/by-sa/4.0/)

aqueous extraction (solubilizes e.g. arabinogalactans), two pectin-solubilizing solutions (ammonium oxalate and dilute hydrochloric acid) as well as two hemicellulose-solubilizing solutions (sodium carbonate and potassium hydroxide) were used and different yields across fractions (Table S2) were obtained. The monosaccharide composition varied after sequential extractions and among species (Fig. 2; Table S3).

GC-chromatograms revealed the well-known monosaccharides and a combination of two further peaks (Fig. 3), which were identified by mass spectrometry as two acetylated derivatives (Fig. $3 \mathrm{a}$ and $3 \mathrm{~b}$ ) of the unusual branched-chain pentose Api, as confirmed by analysis of a commercial DL-Api standard (Fig. 3c).
The water-soluble fraction a (Fig. 2) showed a strikingly different constituent monosaccharide composition compared to the other fractions with high amounts of Gal and arabinose (Ara, see also Table S3). These neutral monosaccharides are the main components of arabinogalactan-proteins (AGPs), as well as arabinan and galactan side-chains of pectins. They were detected in combined values of approximately 27-85 mol-\%. The principal component analysis (PCA, Fig. S1) showed that these two monosaccharides were positively correlated. Preliminary results with $\beta$-glucosyl-Yariv reagent $(\beta G l c Y)$, a specific dye for AGPs, supported the presence of AGPs (Pfeifer and Classen, unpublished data).

\section{(See figure on next page.)}

Fig. 2 Circular stacked bar plot showing monosaccharide composition of five different fractions after sequential extraction of the different total seagrasses. Solvents: $\mathbf{a}$ : water, $\mathbf{b}$ : ammonium oxalate, $\mathbf{c}$ : hydrochloric acid, $\mathbf{d}$ : sodium carbonate, e: potassium hydroxide. The bar represents neutral monosaccharides + uronic acids $=100 \%$. Therefore, uronic acids make up the blank space up to $100 \%$, thus leading to a negative correlation of the height of the bar and the uronic acid content. For further clarification, detailed values for neutral monosaccharides in \% (mol/mol) and uronic acids in \% (w/w) are given in Table S3. Aa: Amphibolis antarctica, Cn: Cymodocea nodosa, Ea: Enhalus acoroides, Th: Thalassia hemprichii, Pa: Posidonia australis, Ps: Posidonia sinuosa, R: Ruppia sp., Zm: Zostera marina, Zn: Zostera noltii 


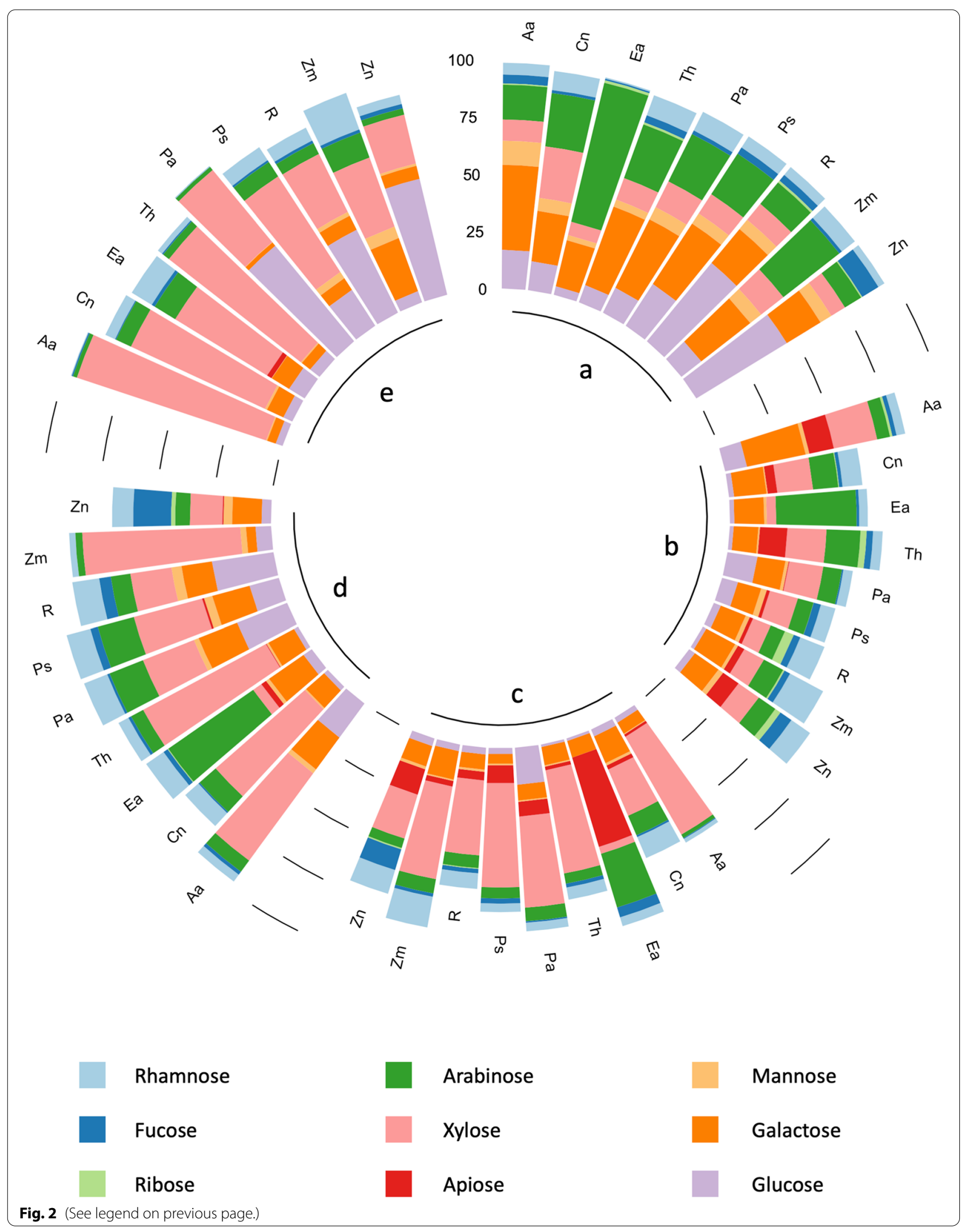



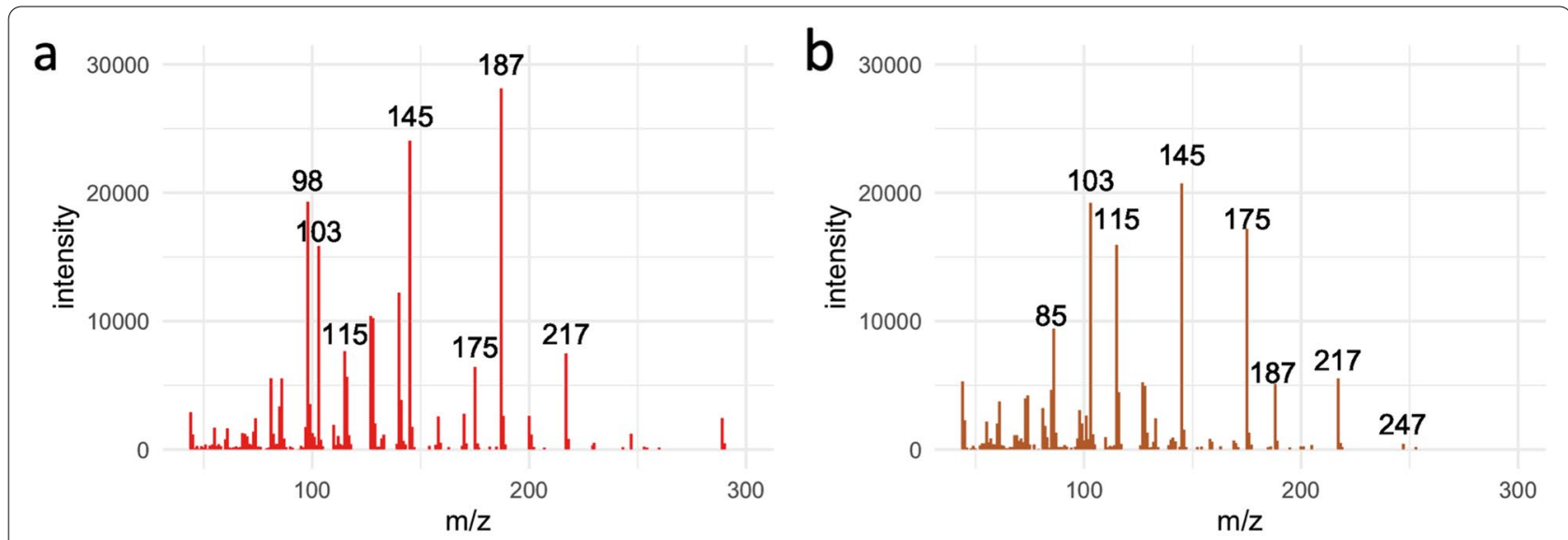

C

180000

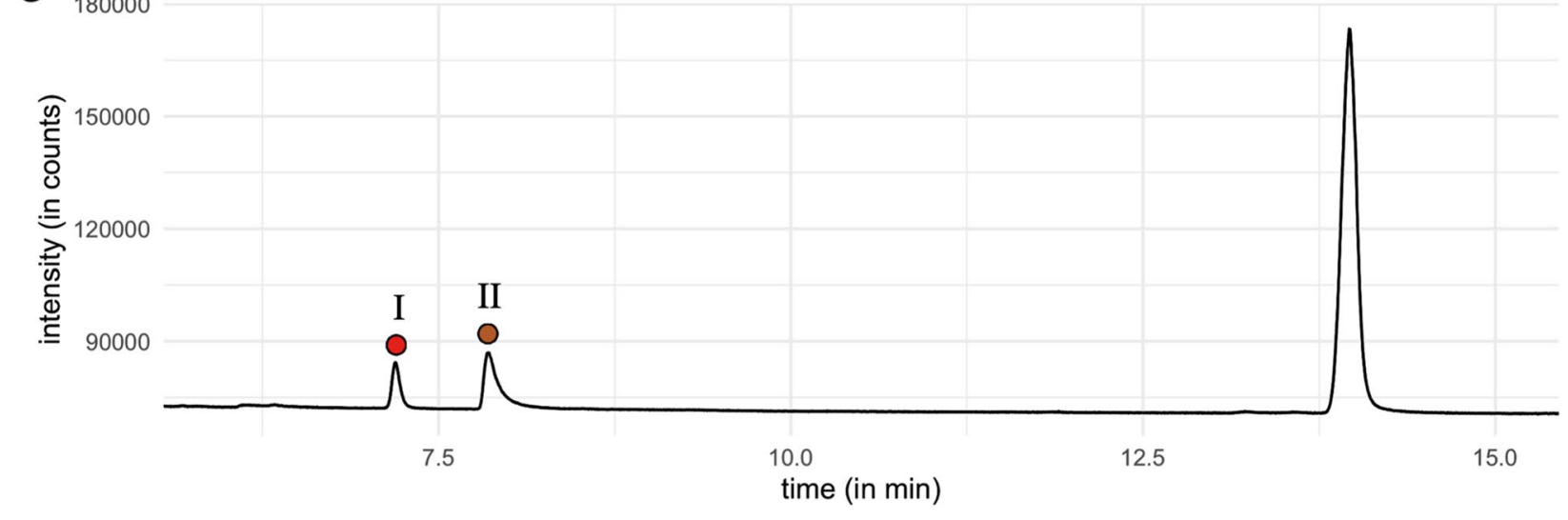

d

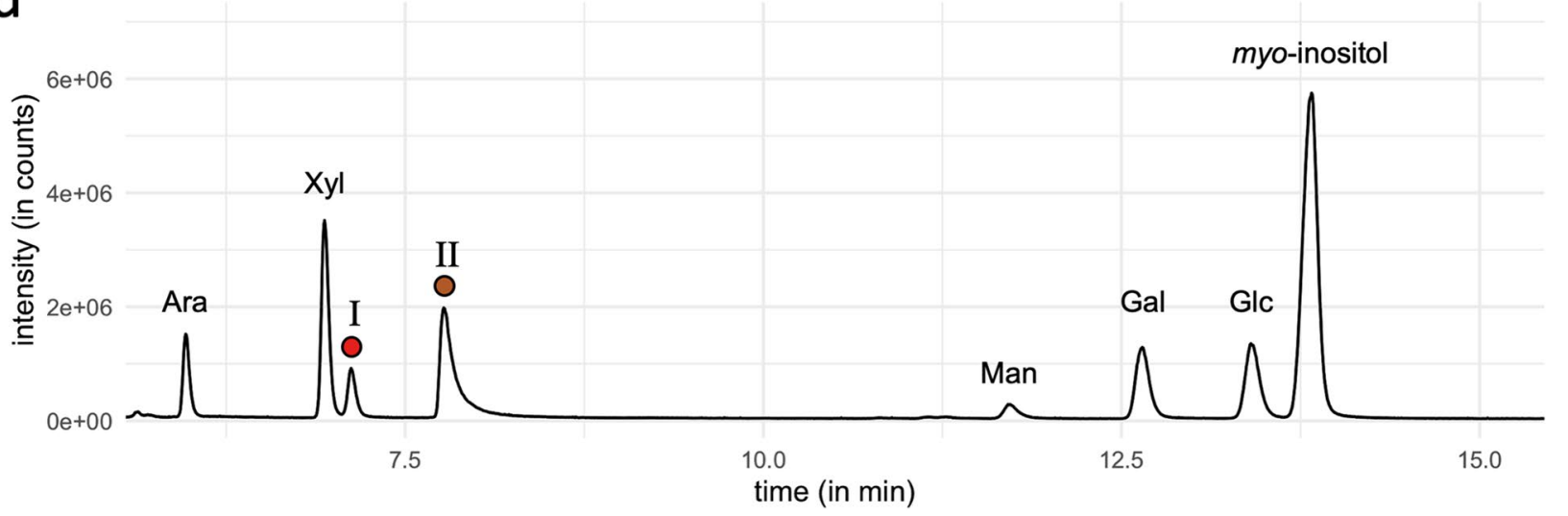

Fig. 3 Identification of the unusual constituent monosaccharide apiose. a: Electron impact (El) mass spectrum of the detected apiitol-tetra-acetate. b: El mass spectrum of the detected apiitol-penta-acetate. c: Gas chromatogram of the apiose standard with apiitol-tetra-acetate (I) and apiitol-penta-acetate (II). The internal standard myo-inositol appears at approximately $13.5 \mathrm{~min}$. $\mathbf{d}$ : Gas chromatogram of neutral monosaccharides from E. acoroides leaves. Apiose peaks are highlighted by colored dots

Fractions $\mathrm{b}$ and $\mathrm{c}$ isolated by acidic solvents (Fig. 2) represented important similarities, with higher uronic acid and Api contents compared to the other fractions. A PCA-biplot (Fig. S1) underlined this correlation with a low angle of the corresponding loading plots. The ammonium oxalate extract (fraction b) had the highest amounts of uronic acids and the hydrochloric acid extract (fraction c) was richer in xylosyl residues (Xyl).

Finally, the two fractions ( $\mathrm{d}$ and e) isolated by alkaline solvents (Fig. 2) were characterized by Xyl and glucosyl 
(Glc) units dominating the monosaccharide composition with two exceptions in the sodium carbonate fraction (fraction d, E. acoroides and Z. noltii). Dominance of Xyl and Glc was more pronounced in fraction e isolated by potassium hydroxide.

\section{Comparison of the carbohydrate compositions of the different species}

The different families (Posidoniaceae, Zosteraceae, Hydrocharitaceae, Cymodoceaceae and Ruppiaceae) and the different habitats (Baltic, Mediterranean, Red Sea and the Indian Ocean) possess a similar cell wall composition of all nine species in terms of polysaccharides in the different fractions (Fig. 2 and Table S3). Species clearly differed in constituent monosaccharide composition of the different polysaccharides. The dominating monosaccharides Xyl and Glc (possibly xyloglucans) in fraction e show higher amounts of Xyl in the Cymodoceaceae and Hydrocharitaceae contrasting the higher amounts of Glc in the other families. The relative amount of Xyl increased from the aqueous to the potassium hydroxide fraction in all investigated species. Fucosyl (Fuc) residues were only detectable in substantial amounts in $Z$. noltii, especially in the hydrochloric acid and carbonate fractions. E. acoroides differed from all other species, with exceptionally high amounts of Ara residues in fractions a-d. This observation was consistent with the results for the different organs (Fig. 4). E. acoroides was also the only species lacking Api in the ammonium oxalate extract, but presented an extremely high amount (47.5 mol-\%) of this unusual monosaccharide in the hydrochloric acid fraction.

\section{Monosaccharide composition of different organs of four seagrass species}

Four representative seagrass species (one of each family) were separated into the different organs (leaves, rhizomes and roots) and analyzed for their constituent monosaccharide composition. (Fig. 4a and b). An additional plant organ - the sheaths at the connection point of leaves and rhizome - was also analyzed in P. australis. Neutral monosaccharides with $\mathrm{Xyl}$ or Glc residues dominated in all samples, with exception of leaves and roots of $E$. acoroides. Leaves and roots of all species contained more Api compared to the rhizomes, which were rich in Glc.

$A$. antarctica showed the most homogeneous monosaccharide composition of all organs, characterized by high amounts of Xyl residues (between 48.0 and 73.3 mol-\% of neutral monosaccharides).

E. acoroides presented the highest amounts of Api, especially in leaves (30.6 mol-\%) and roots (28.8 mol-\%) and also the highest amounts of Ara (up to 11.5 mol-\%). The rhizomes were overall much richer in Glc compared to the leaves and roots.

Glc (65.6 mol-\%) was the dominating neutral monosaccharide in $P$. australis rhizomes, whereas Xyl was more abundant in leaves, roots and sheaths (45.3-63.9 mol$\%)$. The monosaccharide composition of sheaths, which are remains of dead leaves, resembled that of the leaves. In contrast to all other species, roots of $P$. australis were depleted in uronic acids. All organs of both Australian species, $A$. antarctica and $P$. australis, were enriched in Xyl units compared to E. acoroides and Z. marina.

Glc was highest in rhizomes compared to the other organs for E. acoroides, $P$. australis and $Z$. marina, while Gal and Rha were more abundant in all $Z$. marina organs compared to the other species. Uronic acids (6.7-8.7 $\% \mathrm{w} / \mathrm{w}$ ) were significantly more abundant in all $Z$. marina organs compared to the other species (Fig. 4b).

\section{Microscopical detection of lignin in Z. marina}

Lignified tissues can be detected by different staining methods, each with its own (and different) molecular interaction partner. Staining was performed with cross sections of $Z$. marina rhizomes (Fig. 5a, b, c, e and g) and cross sections of Mentha x piperita (Lamiaceae) stems as positive control (Fig. 5d, f and h). Z. marina rhizome has an epidermis (Ep) and a broad cortex $(\mathrm{C})$ of parenchyma cells with a bigger central stele (S) and two smaller cortical vascular bundles $(\mathrm{Cv})$ [see 40]. Each vascular bundle is surrounded by an endodermis (En). The control shows a part of the vascular bundle of $M$. piperita with Xylem $(\mathrm{X})$ and Phloem (P).

Mäule staining - specifically staining syringyl lignin subunits $[40,41]$ showed no red color in $Z$. marina (Fig. 5c), whereas the tissue of $M$. piperita (Fig. 5d) showed an intense red dye coloring indicating the presence of lignin, especially in the xylem (X).

Given this S-unit specificity, two additional stainingtypes were performed. The classical staining method of Wiesner with phloroglucinol/hydrochloric acid, specific for cinnamaldehyde end-groups, but independent of the subunit type, locates the lignin-containing region by formation of red to pink color [40]. The positive control clearly showed the xylem $(\mathrm{X})$ of $M$. piperita in pink (Fig. 5f), but failed to stain $Z$. marina intensively. A slight pink color was detected in some sections mainly in the endodermal region (En; Fig. 5e). Since the Wiesner method, in fact, only detects a very minor substructure of lignin - cinnamaldehyde end-groups are generally very low in abundance in wildtype plants [42], the Wiesner staining might not be sufficiently sensitive to pick up the low levels of lignin expected for $Z$. marina. 


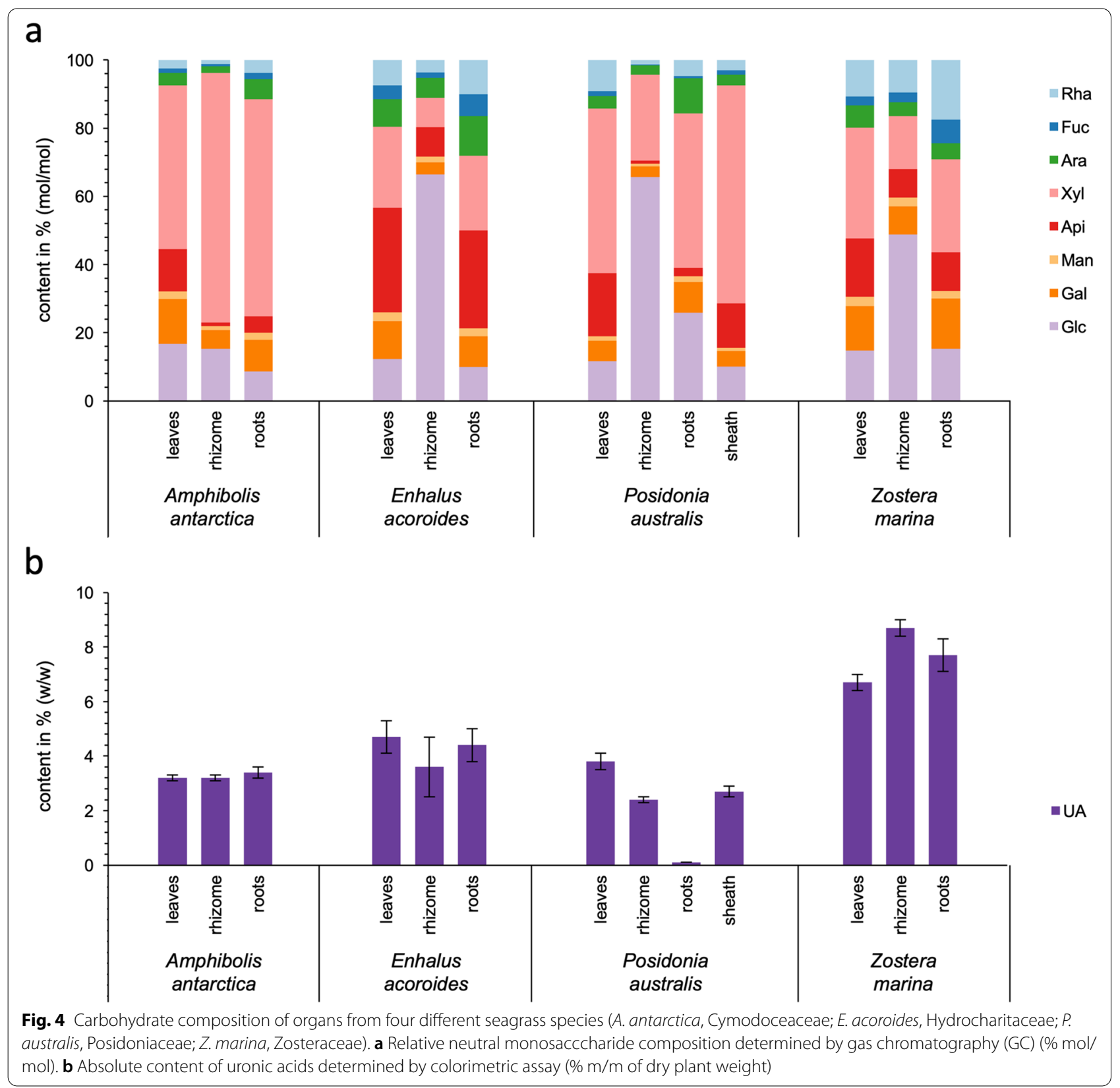

Secondly, safranin-astra blue - a differential staining procedure with two dyes - was used to differentiate lignin in light red from cellulose in blue [43]. The staining failed to detect any lignin in the cell walls of $Z$. marina (Fig. 5g), but did develop the expected lignin coloring for
M. piperita (Fig. 5h). Lignin was expected to be present in at least some of our species, so all samples were further subjected to in-depth analysis by ${ }^{13} \mathrm{C}$-IS pyrolysisGC-MS, which provides a more accurate and sensitive detection compared to staining techniques.

(See figure on next page.)

Fig. 5 Micrographs of Z. marina rhizome and Mentha x piperita stem sections after staining with different methods to detect lignin. Zostera: S: central stele (central cylinder); C: cortex; Cv: cortical vascular bundle; En: endodermis; Ep: Epidermis. Mentha: X: xylem; P: phloem. a: Unstained cross section of $Z$. marina rhizome with central stele. A small vascular bundle is located within the black frame. $\mathbf{b}$ : Enlargement of unstained small vascular bundle of Z. marina. Three different staining methods for Z. marina (left) and Mentha x piperita with lignified xylem (right). c + d: Mäule-staining. $\mathbf{e}+\mathbf{f}$ : Wiesner-staining. $\mathbf{g}+\mathbf{h}$ : Safranin-astra blue staining 


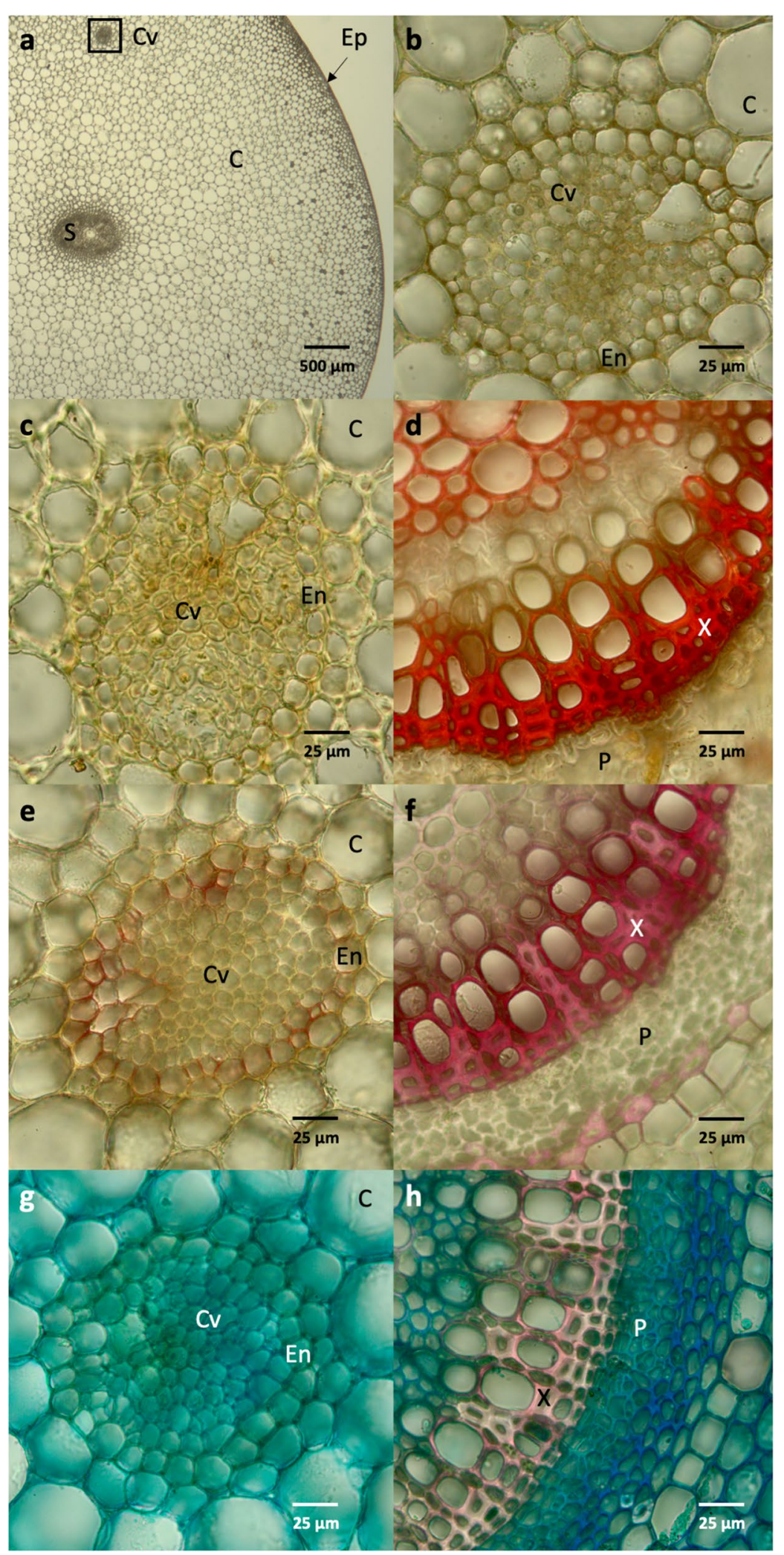

Fig. 5 (See legend on previous page.) 
Lignin analysis by ${ }^{13} \mathrm{C}-$ IS pyrolysis-GC-MS

The different tissues of four selected seagrass species, as representatives of the respective families, were analyzed by quantitative ${ }^{13} \mathrm{C}$-IS pyrolysis-GC-MS, employing a ${ }^{13} \mathrm{C}$ lignin isolate as internal standard $\left({ }^{13} \mathrm{C}-\mathrm{IS}\right)$. This selective and sensitive method specifically monitors lignin-derived pyrolysis products to measure total lignin content (and structure), by correlation to the ${ }^{13} \mathrm{C}$ IS lignin [34]. The internal standard used in this analysis was isolated from ${ }^{13} \mathrm{C}$ wheat straw [34], and hence, provided an 'ideal' standard for herbaceous biomass sources [35]. We are confident that, though the method was optimized for terrestrial grasses, it still allows for a (relative) comparison among seagrasses [35].

The analysis showed substantial levels of lignin, that varied both by species and tissue type, when 'all' $p$-hydroxyphenyl, guaiacyl and syringyl pyrolysis products were included (Fig. 6a). Aromatic amino acids also form $p$-hydroxyphenyl products upon pyrolysis, and if present in considerable amounts, can interfere with the analysis of lignin [34]. Relatively high levels of indole, a marker used to indicate the abundance of aromatic amino acids, and thereby abundance of proteins [44], were detected in the pyrograms (Fig. S2). The indole abundance exceeded that of a reference wheat straw sample by at least a factor of 1.6, confirming that the samples contained relatively high amounts of (interfering) aromatic amino acids compared to that of lignin, especially considering the overall lower lignin contents compared to that of the wheat straw reference $(19.4 \% \mathrm{w} / \mathrm{w})$. Hence, we decided to exclude these $p$-hydroxyphenyl products in the calculations of lignin content, thereby conservatively providing 'true' lignin contents for the seagrass samples (Fig. 6b).

The exclusion of $p$-hydroxyphenyl products confirmed the difference in lignin contents among species and organs. The root and rhizome lignin contents in A. antarctica $(4.7 \%$ and $10.5 \% \mathrm{w} / \mathrm{w}$, respectively) were
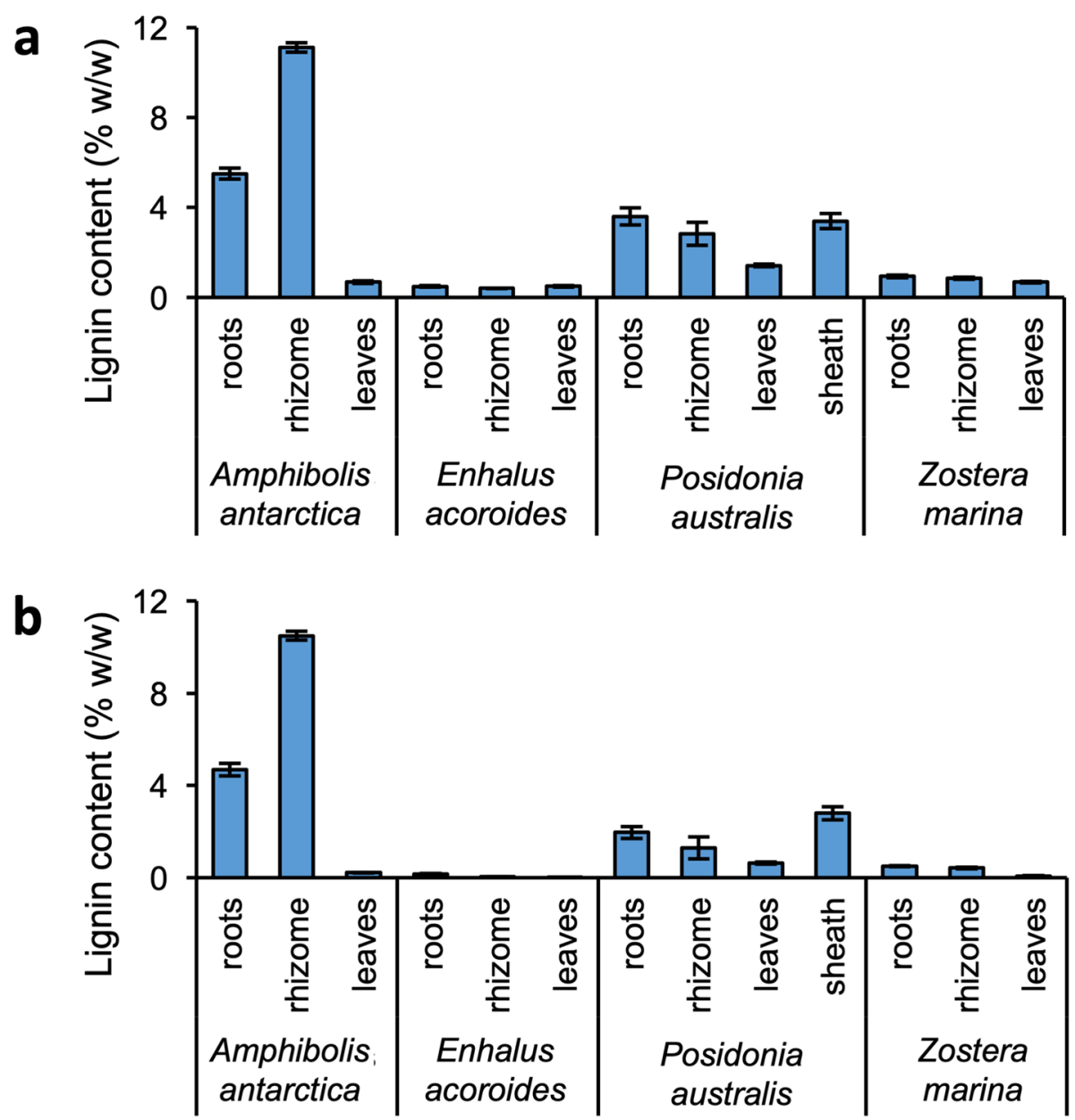

Fig. 6 Lignin content as determined by quantitative ${ }^{13} \mathrm{C}-$ IS pyrolysis-GC-MS, including 'all' lignin-derived pyrolysis products (a) and excluding $p$-hydroxyphenyl products, also derived from aromatic amino acids (b). Average and standard deviation of technical triplicates 
significantly higher than in the leaves and in the three other species. These tissues were also shown to contain appreciable amounts of 'true' lignin in $P$. australis, respectively at 2.0 and $1.3 \%(\mathrm{w} / \mathrm{w})$. The sheath tissue of $P$. australis was also substantially lignified $(2.8 \% \mathrm{w} / \mathrm{w})$. The roots and rhizomes of $Z$. marina contained very small amounts of lignin $(0.5 \% \mathrm{w} / \mathrm{w})$, in line with previous reports by Klap et al. [29].

The lignified tissues of $A$. antarctica and $P$. australis differed in absolute lignin contents and lignin structure (Table 1). The lignin in A. antarctica tissues was found to be richer in syringyl units, with $\mathrm{S} / \mathrm{G}$ ratios of the roots $(\sim 0.7)$ and rhizomes $(\sim 0.8)$, respectively, compared to that of $P$. australis ( 0.2). The sheath tissues of $P$. australis were relatively enriched in syringyl units compared to the other lignified tissues, approximately by a factor two (S/G 0.4).

A further subdivision of the structural moieties showed that lignins structurally differed beyond the subunit level (Table 1) among organs and species. For the lignin populations of $P$. australis roots and rhizomes this implied that the fine structures presumably still varied in terms of linkage motifs, at least to some extent. The analysis also provided insights into the relative distribution of carbohydrate-derived pyrolysis products, thereby

Table 1 Relative abundance of lignin-derived compounds. ${ }^{13} \mathrm{C}$ IS py-GC-MS relative abundance of lignin-derived compounds of the lignified tissues of $A$. antarctica and P. australis, excluding $p$-hydroxyphenyl products also derived from aromatic amino acids. Corrected for relative response factors and the relative abundance of ${ }^{13} \mathrm{C}$ structural analogues. Summed on the basis of structural classification according to Del Río et al. [45] and Van Erven et al. [46]. Average and standard deviation of technical triplicates

\begin{tabular}{|c|c|c|c|c|c|}
\hline & \multicolumn{2}{|c|}{$\begin{array}{l}\text { Amphibolis } \\
\text { antarctica }\end{array}$} & \multicolumn{3}{|c|}{ Posidonia australis } \\
\hline & roots & rhizome & roots & rhizome & sheath \\
\hline \multicolumn{6}{|c|}{ Lignin subunits (\%) } \\
\hline G & $59.7 \pm 1.0$ & $55.0 \pm 0.7$ & $84.0 \pm 0.5$ & $84.0 \pm 1.9$ & $71.2 \pm 3.0$ \\
\hline$S$ & $40.3 \pm 1.0$ & $45.0 \pm 0.7$ & $16.0 \pm 0.5$ & $16.0 \pm 1.9$ & $28.8 \pm 3.0$ \\
\hline$S / G$ & $0.7 \pm 0.0$ & $0.8 \pm 0.0$ & $0.2 \pm 0.0$ & $0.2 \pm 0.0$ & $0.4 \pm 0.0$ \\
\hline \multicolumn{6}{|c|}{ Structural moieties (\%) } \\
\hline Unsubstituted & $10.2 \pm 0.4$ & $8.9 \pm 0.1$ & $10.9 \pm 0.5$ & $10.6 \pm 0.9$ & $9.7 \pm 0.5$ \\
\hline Methyl & $5.3 \pm 0.1$ & $5.3 \pm 0.2$ & $6.6 \pm 0.1$ & $6.6 \pm 0.1$ & $7.6 \pm 0.9$ \\
\hline Vinyl & $29.6 \pm 1.1$ & $24.7 \pm 0.3$ & $33.5 \pm 0.6$ & $29.9 \pm 0.7$ & $30.9 \pm 0.7$ \\
\hline$C_{a}-0 x$ & $4.8 \pm 0.1$ & $5.1 \pm 0.0$ & $6.1 \pm 0.1$ & $6.0 \pm 0.3$ & $7.6 \pm 0.1$ \\
\hline$C_{\beta}-O x^{a}$ & $1.6 \pm 0.0$ & $1.9 \pm 0.0$ & $2.4 \pm 0.0$ & $2.7 \pm 0.5$ & $4.4 \pm 0.3$ \\
\hline $\mathrm{C}_{Y}-\mathrm{OX}$ & $38.0 \pm 2.1$ & $43.2 \pm 0.8$ & $30.9 \pm 1.0$ & $35.8 \pm 3.5$ & $28.1 \pm 1.3$ \\
\hline Miscellaneous & $10.6 \pm 0.7$ & $10.9 \pm 0.2$ & $9.6 \pm 0.2$ & $8.5 \pm 1.0$ & $11.6 \pm 0.1$ \\
\hline $\mathrm{PhC}_{\gamma}^{\mathrm{b}}$ & $49.7 \pm 1.6$ & $55.9 \pm 0.6$ & $41.9 \pm 1.1$ & $46.4 \pm 2.5$ & $43.4 \pm 1.2$ \\
\hline
\end{tabular}

${ }^{a}$ excluding diketones. ${ }^{b}$ phenols with intact $a, \beta, \gamma$ carbon side chain complementing the results obtained by constituent monosaccharide analysis (Fig. S4).

\section{Discussion}

Sequential extraction of polysaccharide fractions from nine seagrass species

The water-soluble fractions of all seagrass species analyzed here were dominated by Gal and Ara, indicating the presence of arabinogalactans or/and arabinogalactanproteins. Preliminary results with $\beta$-glucosyl-Yariv reagent $(\beta G l c Y)$, a specific dye for AGPs, supported the presence of AGPs in this fraction in all investigated seagrass species (Pfeifer and Classen, unpublished data). Knowledge on AGPs in seagrass cell walls is limited. Pettitt (1980) showed that pollen of T. hemprichii were stained by $\beta$ GlcY, [47]. Recently, isolation and characterization of an AGP from a seagrass was successfully performed and revealed unusual features such as a high degree of branching and a high content of terminating 4-O-methyl-glucuronic acid (4-OMe GlcA) residues [48]. Our results show, for the first time, that occurrence of AGPs seems to be a common feature of seagrass species from all families and all habitats.

The constituent monosaccharide composition of the ammonium-oxalate fraction with uronic acids, Api, Gal, Ara, Xyl and Rha showed that pectic polysaccharides are present, as expected for this type of extracts. The group of pectins include the major polysaccharides homogalacturonan (HG), rhamnogalacturonan I (RG-I), rhamnogalacturonan II (RG-II) and xylogalacturonan (XGA) (for review see $[49,50])$. Up to now, investigations on Zostera cell walls revealed evidence for presence of $\mathrm{HG}[51,52]$ and RG-I [21, 51]. The presence of Rha in the fractions isolated with ammonium oxalate and hydrochloric acid suggests that RG I is also present in the cell walls of the seagrasses investigated here. All investigated seagrass species are distinct from terrestrial flowering plants as they contained substantially higher amounts of Api, most likely derived from apiogalacturonan (AGA). The Lemnoidae (subfamily of the Araceae), which are also non-commelinid monocots and members of the order Alismatales, are the only other flowering plants known to have cell walls with AGA $[53,54]$. This special pectic polysaccharide has a $(1 \rightarrow 4)$-linked $\alpha$-D-GalA backbone that is substituted at $O-2$ with single Apif residues or short oligosaccharides of Apif.

AGA in seagrasses was first isolated from Zostera [55], further studied [56] and structurally characterized [21, 52]. High contents of Api have also been found in P. australis [57] and Heterozostera tasmanica [58]. There are intergeneric differences in the composition of pectin subclasses in the duckweeds, especially in the group of substituted HGs. AGAs are dominant in the ammonium 
oxalate fraction of Spirodela, Landoltia and Lemna, whereas Wollfiella species contain mainly Ara and in the latest diverging genus Wolffia, XGAs are most abundant [53]. Interestingly, RG-II, which is strongly conserved in the plant kingdom [59] and also present in the aquatic Lemnoideae [53], also contains small amounts of Api, but has not been described in any seagrass. The presence of AGA- and RG-II domains has been proposed in the lemnoids [53]. A typical feature of RG-II is presence as borate cross-linked dimer. Lemna cell walls have been reported to contain high amounts of boron, but only a small portion is associated with RG-II [60]. Hence it has been proposed, that most of this boron is derived from borate esterified AGAs [53]. This suggests the isolation and characterization of AGA and RG-II from cell walls of seagrasses to be a productive path for future research.

The seagrass fractions isolated by diluted hydrochloric acid were probably also pectin-rich, with the difference that Xyl content was higher compared to the ammonium oxalate fractions. One reason might be the presence of XGAs, which are also known from the Lemnoideae. Members of the most recently evolved genus in this subfamily, Wolffia, show a higher prevalence of XGA than AGA [53].

The monosaccharide composition in both fractions soluble in acidic solvents was very different in $E$. acoroides. It is the only species which contained no Api in the ammonium oxalate extract, but an extremely high amount (nearly 50\%) of this monosaccharide in the hydrochloric acid fraction, indicating differences in the fine structure of the AGAs with different solubility. Furthermore, exceptional high amounts of Ara in both fractions of $E$. acoroides are striking. It seems unlikely, that these amounts are present only in side chains of RGs. Another possibility would be that singular arabinans are abundant in this species. Arabinans may occur separately or as side chains of rhamnogalacturonan I and are composed of a backbone of $\alpha-(1 \rightarrow 5)$-linked Araf units, which can be substituted at positions $\mathrm{O} 2, \mathrm{O} 3$, and both $\mathrm{O} 2$ and O3 with monomeric or oligomeric Ara side chains [61]. Cell walls of the genus Wolffiella (Lemnoideae) are also characterized by a high Ara content [53]. The littoral species $E$. acoroides belongs to the Hydrocharitaceae, a family which includes freshwater and marine species. It is the only seagrass species which does not complete its life cycle entirely under water [2]. E. acoroides is dioecious, with male flowers dehiscing and floating on the water surface to pollinate female flowers: the pollen and the styles remain dry [62].

$\mathrm{Xyl}$ or Glc are dominating in the fractions isolated by sodium carbonate, with exception of E. acoroides, where again Ara is the main monosaccharide with over 50 mol$\%$, and Z. noltii with high Fuc content (see below). Xyl and Glc are typical monosaccharides of plant hemicelluloses, especially xylans and xyloglucans and in some species also mixed-linked glucans. Xylans are major components of secondary cell walls in terrestrial plants. They have a backbone consisting of $(1 \rightarrow 4)$-linked $\beta$-D-Xylp with a high degree of substitution with Araf (sometimes substituted with ferulic acid) and/or (4OMe)-GlcA [6365]. Side chains containing Ara $p$ are most abundant in the arabinopyranosyl-containing glucuronoxylans of the Alismatales [63] and might therefore also be present in seagrass cell walls. Xylans have been detected in cell walls of Halophila species [66] and Z. marina [17], although the exact structure of seagrass xylans is unknown. Xyloglucans consist of $(1 \rightarrow 4)$-linked $\beta$-D-Glc which are substituted with $\alpha-\mathrm{D}-\mathrm{Xyl}$ chains at $O-6$. Fucogalactoxyloglucans are common in walls of non-commelinid monocotyledons and might occur especially in the carbonate fraction of $Z$. noltii with high Fuc content. Fuc was not detected in the same fraction of Z. marina in this study. In a study with the monoclonal antibody CCRCM1, which recognizes the epitope structure $\alpha$-Fuc- $(1,2)-\beta$-Gal of fucogalactoxyloglucans, labelling of Zostera muelleri was weak and restricted to the phloem sieve elements [67].

In the fractions isolated by potassium hydroxide, dominance of Xyl and Glc was striking. Xyl was present in very high amounts in the Hydrocharitaceae and the Cymodoceaceae (between 53.2 and 89.4 mol-\%). Xyl was less pronounced (between 24.4 and 53.6 mol-\%) in the Posidoniaceae, Ruppiaceae and Zosteraceae and accompanied by appreciable amounts of Glc. Further investigations of xylans and xyloglucans of seagrasses are required to elucidate the fine structures of these polysaccharides in these marine organisms.

\section{Constituent monosaccharide composition of different organs of four seagrass species}

The monosaccharide composition of all organs in A. antarctica was quite homogeneous and characterized by high amounts of Xyl (48.0-73.3 mol-\%). The organs of all other species differed in their compositions. The rhizomes of E. acoroides, P. australis and Z. marina were characterized by higher amounts of Glc (48.8-66.4 mol\%) compared to leaves and roots, and in case of $P$. australis also sheaths. Rhizomes are persistent and the main storage organs for soluble carbohydrate reserves. Sucrose has been identified in most seagrasses as main carbohydrate storage molecule, while also starch is found [68]. Starch supports the storage function in aboveground tissues and sucrose in belowground plant parts [69]. The rhizome of $A$. antarctica is very thin and therefore not capable of storing as much carbohydrate reserve as both Posidonia species. Xyl residues are more abundant in $A$. 
antarctica and P. australis, a feature which might be correlated to the occurrence of lignin.

\section{Lignin in different seagrasses}

Our results highlight the sensitivity of the ${ }^{13} \mathrm{C}$-IS pyrolysis-GC-MS technique for evaluating lignin contents, and given this sensitivity our analyses show that $E$. acoroides contains a negligible amount of lignin. Likewise, leaves contained negligible amounts of lignin in all species, except those of $P$. australis [25-28], which showed approximately $0.6 \%(\mathrm{w} / \mathrm{w})$ lignin.

The lignin contents for $P$. australis were substantially lower than those reported by Kaal et al. [36] for P. oceanica. First and foremost, the gravimetric method used previously to determine lignin [36] can overestimate lignin contents due to its low selectivity, and is expected to include considerable amounts of ash, protein, and tannin, amongst other non-extractable phenolic oligomers and polymers [33, 70]. Indeed, substantial tannin/ polyphenol-derived pyrolysis products (e.g., catechol, methylcatechol, methoxycatechol and gallic acid) were also detected in our samples (Fig. S3). Moreover, Kaal et al. [36] prepared extractive-free cell wall residues, while we measured the samples in their entireties, which further contributes to the relatively lower lignin contents reported here.

Lignin is commonly considered to provide plants with mechanical strength and rigidity, i.e. allowing plants to grow upward, which logically is a feature of lesser relevance in an underwater environment [71]. Tougher plants might still be better protected against stronger currents and, hence, the presence of lignin might be an evolutionary advantage in this context. Lignin is known to provide protection against pathogenic microbes [72], which may benefit seagrass [73]. In contrast to that, retention of lignin might also be understood as redundant artifact of their terrestrial ancestors. Our results provide evidence for differential seagrass evolution relative to the lignification of their cell walls. Genetic engineering of the seagrasses $A$. antarctica and P. australis, primarily targeted to modify their lignin biosynthetic pathways, might be of help for answering these questions [74].

The presence of lignin correlated well with the abundance of Xyl residues, which presumably is a measure of xylan abundance in these organs and, hence, could indicate that some general features of terrestrial secondary cell walls have been conserved in some seagrass species. Xyl residues in terrestrial grasses are mainly part of glucuronoarabinoxylans, which are involved in the covalent cross-linking to lignin via diferulic acid moieties to form so-called lignin-carbohydrate complexes [64]. Indeed, substantial amounts of ferulic acid have been detected in P. oceanica lignins [37].

\section{Adaptation of seagrasses to the marine environment}

Cell walls of marine algae are characterized by polysaccharides with high charge, e.g. the polyanionic alginates and fucose-containing sulfated polysaccharides of the brown algae [75] or the sulfated galactans of the red algae [76]. Sulfated galactans also occur in cell walls of some green algae (e.g. [77]) and have been detected in the seagrasses C. nodosa, Halodule wrightii, Halophila decipiens and in the facultative marine angiosperm Ruppia maritima [18-20]. The amount of this sulfated galactan in Ruppia increased with salinity and disappeared in culture without salt supplement [78].

Additional components of seagrass cell walls might be involved in adaptation to the marine environment. It has been shown that salt stress upregulates periplasmic arabinogalactan proteins [79]. These glycoproteins have been isolated from $Z$. marina and are characterized by a high content of glucuronic acid (GlcA) residues in general and terminal 4-OMe-GlcA in particular [48]. Structure-dependent calcium-binding by AGPs could putatively help the plant to discriminate against binding of $\mathrm{Na}^{+}$[80]. Comparison of transcriptomic data for Zostera grown with and without $\mathrm{NaCl}$ revealed that genes involved in calcium-signaling were upregulated after $\mathrm{NaCl}$ treatment [81]. Interestingly, the amount of AGPs in roots and rhizomes of $Z$. marina was around 20 fold higher than in leaves [48], maybe because rhizomes and roots live longer and need increased responsive capacity via signaling AGPs. In the marine angiosperm Ruppia sulfated galactans possibly involved in salt protection are also mainly present in the rhizomes [18]. Arabinans are also known to be involved in salt stress tolerance [82-84]. E. acoroides was very rich in Ara, so in this species arabinans may be important to cope with high salinity.

The most prominent feature of pectins is their uronic acid rich, hence highly charged, structure. We have shown that all seagrasses investigated in this study independent of family assignment or habitat possess high Api contents. This is an important hint for presence of the unusual pectic AGAs, possibly accompanied by other pectic polysaccharides. AGAs have a very low degree of esterification around 10\% [85] and possess stronger ability to bind cations by non-methyl esterified galacturonosyl residues. An increase in the number of pectin methylesterase genes detected in the genomes of two Zostera species seems to be responsible for the low degree of methyl esterification and was understood as putative control mechanism for osmoregulation [13, 14]. In all seagrass species, which we separated into the organs (one of each family), Api was most abundant in leaves, which 
might be a hint towards different mechanisms to cope with salt stress. These could be differentially realized in the separate organs. More studies are needed on occurrence and structures of sulfated galactans, AGPs and pectic polysaccharides of seagrasses to elucidate how special features of seagrass cell walls contributed to one of the most extreme evolutionary events witnessed in the angiosperm lineage.

\section{Evolutionary implications}

Seagrasses belong to the monocotyledonous order of Alismatales, a basal group in flowering plants [5]. The fossil record for seagrasses is limited and patchy, but indicates that ancestors of modern seagrasses evolved successfully in the Tethys Sea during the late Cretaceous [86].

Evolutionary pressures have likely constrained divergence within the group, and in fact, Cretaceous to Miocene aged Posidonia fossils have remained apparently almost unchanged over this long evolutionary history [87]. Molecular data show that seagrasses emerged from a freshwater ancestor of terrestrial origin through at least three independent 'return to the sea' events [2]. A combination of low sequence divergence rates (e.g. [88, 89]) and clonal growth is consistent with a low number of species. In contrast to that, some authors understand the lack of speciation amongst seagrasses as a hint for major extinctions throughout their evolutionary history [86]. Our findings on saccharides present in seagrass cell walls revealed similarities among all species, most prominent the putative occurrence of AGA. AGA is taxonomically restricted to the Alismatales, with Lemnoidae (subfamily of the Araceae) being the only other flowering plants known to have cell walls containing AGA [53, 54]. Our finding of high amounts of Api in all investigated seagrass species, representing the three independent lineages, suggests the unusual pectic polysaccharide AGA was already present in terrestrial ancestors and not the result of convergence among independent seagrass lineages.

During diversification of the Lemnoideae from lemnoids (Spirodela, Landoltia and Lemna) to wolffioids (Wolffiella and Wolffia), AGA decreased substantially $[53,90]$. Amounts of Api in seagrass cell walls are more similar to lemnoid species than to wolffioids. In Wolfiella species, high amounts of Ara are present, a feature we also detected in E. acoroides cell walls. E. acoroides is also outstanding from an ecological perspective as it is the only seagrass that is not hydrophilous.

Further differences comprise putative xylans and/ or xyloglucans in the fractions isolated by potassium hydroxide. In the Hydrocharitaceae and the Cymodoceaceae, Xyl is dominating with up to $90 \%$ (more xylans?), whereas in the Posidoniaceae, Ruppiaceae and
Zosteraceae, Xyl is less prominent and accompanied by appreciable amounts of Glc (more xyloglucans?).

Biosynthesis of lignin has been conserved in the seagrass species $A$. antarctica and $P$. australis. Roots and rhizomes of $A$. antarctica and in case of $P$. australis also sheaths contain lignin in amounts comparable to duckweed species [90]. E. acoroides and Z. marina are nearly lignin-free. Probably, the biosynthetic lignin pathway has not been lost in some species, but transcription might be regulated with regard to environmental needs. For example, $A$. antarctica, which has tough, wiry rhizomes and stems that grow up to $2 \mathrm{~m}$ high (in elevated salinities in Shark Bay), had the highest lignin content in roots and rhizomes.

Comparisons with cell walls of freshwater members of the Alismatales will be necessary to distinguish between more general adaptations to the aquatic environment and those specific for the marine environment. The elucidation of fine structures of cell wall components will also help to understand the evolutionary origins of seagrasses.

\section{Conclusions}

Despite the ecological importance of seagrasses, which form important coastal ecosystems worldwide, seagrass cell walls, as a whole, are poorly understood. Comparisons of a greater number of species in different habitats are needed. Our investigations show that all nine species from the different families probably possess similar polysaccharides like arabinogalactans, AGAs, xylans and xyloglucans. High amounts of Api, which is part of the unusual AGAs known from duckweeds and some seagrass species (especially $Z$. marina) have been detected in all investigated seagrass species and AGA might therefore be regarded as common across all seagrasses and possibly their evolutionary ancestors.

However, significant quantitative differences in the monosaccharide compositions were observed among species and plant organs. E. acoroides is outstanding with highest amounts of Api, especially in the fraction isolated by hydrochloric acid, and highest amounts of Ara. Another striking difference of the cell wall compositions are highly variable amounts of lignin. A. antarctica and $P$. australis contain appreciable amounts of lignin, especially in rhizomes and roots and in case of $P$. australis also in sheaths. Z. marina and E. acoroides are nearly free of lignin. Lignin-free cell walls could provide a very interesting raw material for sustainable production of biofuels and materials. Furthermore, the lignified tissues of $A$. antarctica and $P$. australis differed considerably in terms of lignin structure, the lignin of $A$. antarctica being richer in syringyl units compared to that of $P$. australis. The retention of lignin during evolution from terrestrial vascular plants back to the sea might be seen as a redundant 
artifact or an evolutionary advantage in marine environments. The lignified rhizomes of $A$. antarctica and $P$. australis might indeed provide strength for anchoring required to grow in areas with strong tidal movement and highly exposed, swell/dominated coastlines.

Our investigations allow comparative insights into the general composition of seagrass cell walls and adaptive cell wall modifications of angiosperms to survive in the marine environment. The comparison of nine species offers information on identical or different strategies of seagrasses with regard to the challenging evolutionary step to life in saltwater. Although the composition of cell walls varied among species and lineages, the sharing of unusual AGAs among seagrasses and Lemnoids suggest some traits predate all 'Return to Sea' events. Further characterization of seagrass polysaccharide and lignin structures, as well as whole genome sequencing of more seagrass species are necessary to understand the evolution of this special group of angiosperms and to adequately protect coastal ecosystems.

\section{Materials and Methods Seagrass material}

Seagrass species native to the Baltic Sea were collected in Kiel-Schilksee (Zostera marina) and Neustadt in Holstein (Ruppia spp. and Zostera noltii).

Other seagrass species were collected and kindly provided by different collaboration partners from Australia (Amphibolis antarctica, Posidonia australis and Posidonia sinuosa, Dr. Elizabeth A. Sinclair, University of Western Australia), Indonesia (Enhalus acoroides, Meri Yulvianti, Kiel University, Germany), Malta (Cymodocea nodosa, Prof. Dr. Joseph A. Borg, University of Malta) and Saudi-Arabia (Enhalus acoroides and Thalassia hemprichii, Prof. Dr. Carlos M. Duarte, KAUST, SaudiArabia). A detailed list of the relevant collection data is provided in Supplementary Table S1.

All seagrass plant material was collected, rinsed in tap water and subsequently dried by a mild drying method (freeze-drying or oven-drying below $60^{\circ} \mathrm{C}$ ).

\section{Sequential extraction of polysaccharides}

Freeze dried seagrass samples (bulk material) of the 9 species were prepared in an IKA MF 10 basic laboratory grinder (sieve size: $1.0 \mathrm{~mm}$; IKA-Werke GmbH \& Co.KG, Staufen, Germany). Milled samples were extracted four times with aceton:water $(70: 30)$ in a ratio of 1:10 $(\mathrm{w} / \mathrm{v})$ overnight under constant shaking on a laboratory shaker (Edmund Bühler $\mathrm{GmbH}$, Bodelshausen, Germany) at $4{ }^{\circ} \mathrm{C}$. The extract was separated by vacuum filtration. An aqueous extraction of the insoluble residue was performed afterwards with double-distilled water under the same conditions. The extract was separated by vacuum filtration and the insoluble residue was subsequentially treated with $0.2 \mathrm{M}$ ammonium oxalate (Carl Roth $\mathrm{GmbH} \&$ Co.KG, Karlsruhe, Germany), $0.1 \mathrm{M}$ hydrochloric acid (diluted from 37\%, p.a., Carl Roth $\mathrm{GmbH} \&$ Co.KG, Karlsruhe, Germany), 3\% (w/v) sodium carbonate (Merck KGaA, Darmstadt, Germany) and $2 \mathrm{M}$ potassium hydroxide (Honeywell Inc., Morristown, NJ, USA). For each step, the insoluble residue was treated with the respective solution in a ratio of $1: 100(\mathrm{w} / \mathrm{v})$ under constant stirring at $70{ }^{\circ} \mathrm{C}$ for $21 \mathrm{~h}$. Each extract was separated from the insoluble residue by centrifugation (Hereus Multifuge X3, Thermo Fisher Scientific Corp., Waltham, MA, USA) at $19.000 \mathrm{~g}$ for $30 \mathrm{~min}$. All extracts were dialyzed for 3 days against demineralized water (MWCO 12-14 kDa, Medicell Membranes Ltd., London, UK), except for the aqueous and the sodium carbonate extract, which were precipitated with absolute ethanol or acetone, respectively, in a final concentration of $80 \%(\mathrm{v} / \mathrm{v})$. After cooling overnight at $4{ }^{\circ} \mathrm{C}$ the precipitate was centrifuged at $4122 \mathrm{~g}$, re-dissolved in demineralized water and freeze-dried (Christ Alpha 1-4 LSC, Martin Christ $\mathrm{GmbH}$, Osterode, Germany). The extraction procedure was done once from the bulk material. A detailed visualized extraction protocol is also provided in the Supporting information of Pfeifer et al. [91].

\section{Neutral monosaccharide composition}

Monosaccharide composition was determined following the acetylation protocol of Blakeney et al. [92], with a modified hydrolysis method. 1-10 mg sample were hydrolysed in $2 \mathrm{M}$ trifluoroacetic acid for $1 \mathrm{~h}$ at $120^{\circ} \mathrm{C}$ (Bioblock Scientific, Thermolyne Corp., Ramsey, MN, USA). $0.5 \mathrm{mg}$ of myo-inositol was included as internal standard. For the crude plant samples, 15-20 mg were used and particles remaining after hydrolysis (e.g. cellulose) were removed by cotton wool filtration. The resulting dichloromethane layer was analysed via GC (Agilent 7890B, Agilent Technologies, Inc., Santa Clara, CA, USA; column: Optima-225, $25 \mathrm{~m}, 0.25 \mathrm{~mm}, 0.25 \mu \mathrm{m}$; flow rate: $1 \mathrm{~mL} / \mathrm{min}$; temperature $230{ }^{\circ} \mathrm{C}$; split ratio $30: 1$ ). The acetylated monosaccharides were determined by GC-FID via retention time with verification through a parallel coupled mass spectrometer (Agilent 5977B MSD, Agilent Technologies, Inc.). Measurements were performed as triplicates, meaning here three independent derivatization experiments with subsequent GC-analysis. Apiose was additionally verified by comparison with a commercially purchased standard (DL-apiose, Carbosynth Ltd., Berkshire, UK). A Principal Component Analysis (PCA) was performed to compare overall monosaccharide composition using RStudio software (version 1.2.5042) with the "ggfortify" package for calculation and biplot visualization [93]. 


\section{Colorimetric quantification of uronic acids}

The content of uronic acids was determined photometrically (UVmini-1240, Shimadzu AG, Kyoto, Japan) by a modified procedure of Blumenkrantz and Asboe-Hansen [94]. $1 \mathrm{mg}$ of polysaccharide sample was dissolved in $2 \mathrm{~mL}$ of sulphuric acid (4\% v/v, prepared from concentrated sulfuric acid p.a., Rotipuran, Carl Roth $\mathrm{GmbH}$ \& Co.KG, Karlsruhe, Germany). A hydrolysis step was performed on crude plant samples using diluted sulphuric acid at $120{ }^{\circ} \mathrm{C}$ for $60 \mathrm{~min}$. These solutions were also standardized to a concentration of $1 \mathrm{mg} / 2 \mathrm{~mL}$. Three measurements (technical replicates) were done and an additional measurement without colouring reagent for each sample was treated as background.

\section{Staining of lignin and microscopical evaluation in Z. marina} Three classical staining methods were used for microscopic evaluation of lignin content in $Z$. marina rhizome. Mentha $\mathrm{x}$ piperita stems (collected from the botanical garden of the Pharmaceutical Institute, Kiel University) were used as a positive control for lignin-containing tissue in all three staining methods. Fresh Z. marina rhizome was collected (Kiel-Schilksee) and cut with a hand-microtome (Euromex Microscopen BV, Arnhem, The Netherlands) into sections of a single cell-layer thick. These were stored in $80 \%$ ethanol until use.

Firstly, Mäule staining (using the protocol of [40]) was performed by applying $0.5 \%$ potassium permanganate solution (prepared from $\mathrm{KMnO}_{4}, \geq 99 \%$, Ph.Eur., Carl Roth GmbH \& Co.KG, Karlsruhe, Germany) to the microscopic sections in a $2.0 \mathrm{~mL}$ microtube with a following incubation time of $2 \mathrm{~min}$. The permanganate solution was then removed from the microtube and the sections were rinsed with double-distilled water until the solution stayed clear. The water was removed and $3 \% \mathrm{HCl}$ (37\%, p.a., Carl Roth GmbH \& Co.KG, Karlsruhe, Germany) was applied two times for about 5 min each until the brown color disappeared. Concentrated ammonium hydroxide was then pipetted into the microtube. The section was investigated under the microscope (Carl Zeiss AG, Oberkochen, Germany).

Secondly, Wiesner staining according to the protocol of [40] was used. Two volumes of a solution of $3 \%(\mathrm{~m} / \mathrm{v})$ phloroglucinol (synthesis grade, Merck KGaA, Darmstadt, Germany) in ethanol ( $\geq 99.8 \%$, p.a., Carl Roth GmbH \& Co.KG, Karlsruhe, Germany) was combined with one volume of concentrated $\mathrm{HCl}$ (37\%, p.a., Carl Roth GmbH \& Co.KG, Karlsruhe, Germany). This solution was transferred onto the slices in a microtube and incubated at room temperature for $1 \mathrm{~min}$. The sections were then investigated microscopically with lignin-containing cells appearing dark pink.
Thirdly, a safranin-astra blue differential staining (modified from [95]) was utilized. A 1\% (m/v) safranin (Merck KGaA, Darmstadt, Germany) solution in double-distilled water and a $0.5 \%(\mathrm{~m} / \mathrm{v})$ astra blue (Merck KGaA, Darmstadt, Germany) solution in 2\% tartaric acid (Merck KGaA, Darmstadt, Germany) were made. The astra blue solution was added to the sections in a microtube and incubated for $5 \mathrm{~min}$, followed by a washing step with double-distilled water. Afterwards, the safranin solution was applied for $5 \mathrm{~min}$ with a subsequent differentiation step in $70 \%$ ethanol. The slices were washed with acidified $70 \%$ ethanol until clear red and blue appearance was visible. All micrographs were obtained by a Canon EOS 1000D (Canon AG, Tokyo, Japan).

\section{Quantitative pyrolysis-GC-MS with ${ }^{13} \mathrm{C}$ lignin as internal standard}

Analytical pyrolysis coupled to gas chromatography with high-resolution mass spectrometric detection (Exactive Orbitrap, Thermo Scientific, Waltham, MA, USA) was performed as previously described [35].

Uniformly ${ }^{13} \mathrm{C}$-labeled lignin $\left(97.7\right.$ atom $\left.\%{ }^{13} \mathrm{C}\right)$, isolated from ${ }^{13} \mathrm{C}$ wheat straw (IsoLife $\mathrm{BV}$, Wageningen, The Netherlands) was used as an internal standard $\left({ }^{13} \mathrm{C}-\mathrm{IS}\right)$ $[34,35]$. To each sample $(80 \mu \mathrm{g}), 10 \mu \mathrm{L}$ of a ${ }^{13} \mathrm{C}$-IS solution $(1 \mathrm{mg} / \mathrm{mL}$ ethanol/chloroform $50: 50 \mathrm{v} / \mathrm{v})$ was added and dried prior to analysis [34]. All samples were prepared and analyzed in triplicate (technical replicates). Lignin-derived pyrolysis products were monitored in full MS mode on the most abundant fragment per compound (both nonlabeled and uniformly ${ }^{13} \mathrm{C}$ labeled). Pyrograms were processed by TraceFinder 4.0 software. Lignin contents and relative abundances of lignin-derived pyrolysis products were calculated, as described previously [35]. Indole, catechol, methylcatechol, methoxycatechol and gallic acid and various carbohydrate-derived pyrolysis products were also monitored in full MS mode on the most abundant fragment per compound, but conversely to lignin without applying response correction.

\section{Supplementary Information}

The online version contains supplementary material available at https://doi. org/10.1186/s12870-022-03447-6.

\section{Additional file 1.}

\section{Acknowledgements}

Thank you to the Malaga Aboriginal Corporation for permission to conduct seagrass research on Gathaagudu (Shark Bay) and to Meri Yulvianti (Kiel University, Germany) and Prof. Dr. Joseph A. Borg (University of Malta) for providing Enhalus acoroides and Cymodocea nodosa, respectively.

\section{Authors' contributions}

L.P. and B.C. planned and designed the research. L.P., E.A.S. and C.D. collected the plant material. L.P. performed the extractions, carbohydrate experiments 
and the microscopy. G.v.E. and M.K. performed the quantitative pyrolysisGC-MS experiments. L.P., B.C., G.V.E. and M.K. analysed the data and wrote the manuscript. All authors discussed and finalized the manuscript. All authors read and approved the final manuscript.

\section{Funding}

Open Access funding enabled and organized by Projekt DEAL. This research was funded by the Deutsche Forschungsgemeinschaft (DFG, German Research Foundation) - project number 456721142 (salary of L.P. and consumables). L.P. received a doctoral scholarship (salary) by Evangelisches Studienwerk Villigst e.V. Salary of E.A.S. was provided by Australian Research Council (DP180100668, DP210101932). All funders had no commercial interest in the project.

\section{Availability of data and materials}

The datasets used and/or analysed during the current study are available from the corresponding author on reasonable request.

\section{Declarations}

Ethics approval and consent to participate

Not applicable

\section{Consent for publication}

Not applicable

\section{Competing interests}

The authors declare that they have no competing interests.

\section{Author details}

${ }^{1}$ Pharmaceutical Institute, Department of Pharmaceutical Biology, ChristianAlbrechts-University of Kiel, Gutenbergstr. 76, 24118 Kiel, Germany. ${ }^{2}$ Laboratory of Food Chemistry, Wageningen University \& Research, Bornse Weilanden 9, 6708 WG Wageningen, The Netherlands. ${ }^{3}$ School of Biological Sciences and Oceans Institute, University of Western Australia, Crawley, WA, Australia. ${ }^{4}$ Red Sea Research Center (RSRC) and Computational Bioscience Research Center (CBRC), King Abdullah University of Science and Technology, Thuwal, Saudi Arabia.

Received: 13 July 2021 Accepted: 11 January 2022 Published online: 04 February 2022

\section{References}

1. Waycott M, Biffin E, Les DH. Systematics and evolution of Australian seagrasses in a global context. In: Larkum AWD, Kendrick GA, Ralph PJ, editors. Seagrasses of Australia. Cham: Springer International Publishing; 2018. p. 129-54. https://doi.org/10.1007/978-3-319-71354-0_5.

2. Les DH, Cleland MA, Waycott M. Phylogenetic studies in Alismatidae, II: Evolution of marine angiosperms (seagrasses) and hydrophily. Syst Bot. 1997;22:443. https://doi.org/10.2307/2419820.

3. Wissler L, Codoñer FM, Gu J, Reusch TB, Olsen JL, Procaccini G, et al. Back to the sea twice: Identifying candidate plant genes for molecular evolution to marine life. BMC Evol Biol. 2011;11:8. https://doi.org/10.1186/ 1471-2148-11-8.

4. Les DH, Tippery NP. In time and with water. The systematics of Alismatid monocotyledons. In: Wilkin P, Mayo SJ, editors. Early events in monocot evolution. Cambridge: Cambridge University Press; 2013. p. 118-64. https://doi.org/10.1017/CBO9781139002950.007.

5. The Angiosperm Phylogeny Group. An update of the Angiosperm phylogeny group classification for the orders and families of flowering plants: APG IV. Bot J Linn Soc. 2016;181:1-20. https://doi.org/10.1111/boj.12385.

6. Strazisar T, Koch MS, Madden CJ. Seagrass (Ruppia maritima L) Life history transitions in response to salinity dynamics along the Everglades-Florida bay Ecotone. Estuaries Coasts. 2015;38:337-52. https://doi.org/10.1007/ s12237-014-9807-4.

7. Tyerman S, Hatcher A, West R, Larkum A. Posidonia australis growing in altered salinities: Leaf growth, regulation of turgor and the development of osmotic gradients. Funct Plant Biol. 1984;11:35. https://doi.org/10. 1071/PP9840035.

8. Nejrup LB, Pedersen MF. Effects of salinity and water temperature on the ecological performance of Zostera marina. Aquat Bot. 2008;88:239-46. https://doi.org/10.1016/j.aquabot.2007.10.006.

9. Hemminga MA, Duarte CM. Seagrasses in the human environment. In: Seagrass ecology. Cambridge University Press; 2000. p. 248-91. https:// doi.org/10.1017/CBO9780511525551.008

10. Valentine JF, Duffy JE. The central role of grazing in seagrass ecology. In: Larkum AWD, Orth RJ, Duarte CM, editors. Seagrasses: Biology, ecology and conservation. Dordrecht: Springer, Netherlands; 2006. p. 463-501. https://doi.org/10.1007/978-1-4020-2983-7_20.

11. Duffy JE, Benedetti-Cecchi L, Trinanes J, Muller-Karger FE, Ambo-Rappe R, Boström C, et al. Toward a coordinated global observing system for seagrasses and marine macroalgae. Front Mar Sci. 2019;6:317. https://doi. org/10.3389/fmars.2019.00317.

12. Pilavtepe M, Celiktas MS, Sargin S, Yesil-Celiktas O. Transformation of Posidonia oceanica residues to bioethanol. Ind Crops Prod. 2013;51:348-54. https://doi.org/10.1016/j.indcrop.2013.09.020.

13. Lee H, Golicz AA, Bayer PE, Jiao Y, Tang H, Paterson AH, et al. The Genome of a southern hemisphere seagrass species (Zostera muelleri). Plant Physiol. 2016;172:272-83. https://doi.org/10.1104/pp.16.00868.

14. Olsen JL, Rouzé P, Verhelst B, Lin Y-C, Bayer T, Collen J, et al. The genome of the seagrass Zostera marina reveals angiosperm adaptation to the sea. Nature. 2016:530:331-5. https://doi.org/10.1038/nature16548.

15. Pfeifer $L$, Classen B. The cell wall of seagrasses: Fascinating, peculiar and a blank canvas for future research. Front Plant Sci. 2020;11: 588754. https:// doi.org/10.3389/fpls.2020.588754.

16. Syed NFN, Zakaria MH, Bujang JS. Fiber Characteristics and papermaking of seagrass using hand-beaten and blended pulp. BioResources. 2016;11:5358-80. https://doi.org/10.15376/biores.11.2.5358-5380.

17. Davies P, Morvan C, Sire O, Baley C. Structure and properties of fibres from seagrass (Zostera marina). J Mater Sci. 2007;42:4850-7. https://doi.org/10. 1007/s10853-006-0546-1.

18. Aquino RS, Landeira-Fernandez AM, Valente AP, Andrade LR, Mourão PAS. Occurrence of sulfated galactans in marine angiosperms: Evolutionary implications. Glycobiology. 2005;15:11-20. https://doi.org/10.1093/ glycob/cwh138.

19. Silva JMC, Dantas-Santos N, Gomes DL, Costa LS, Cordeiro SL, Costa MSSP, et al. Biological Activities of the sulfated polysaccharide from the vascular plant Halodule wrightii. Rev Bras Farmacogn. 2012;22:94-101. https://doi. org/10.1590/S0102-695X2011005000199.

20. Kolsi RBA, Fakhfakh J, Krichen F, Jribi I, Chiarore A, Patti FP, et al. Structural characterization and functional properties of antihypertensive Cymodocea nodosa sulfated polysaccharide. Carbohydr Polym. 2016;151:511-22. https://doi.org/10.1016/j.carbpol.2016.05.098.

21. LvY, Shan X, Zhao X, Cai C, Zhao X, Lang Y, et al. Extraction, isolation, structural characterization and anti-tumor properties of an apigalacturonan-rich polysaccharide from the seagrass Zostera caespitosa MIKI. Mar Drugs. 2015;13:3710-31. https://doi.org/10.3390/md13063710.

22. Boerjan W, Ralph J, Baucher M. Lignin biosynthesis. Annu Rev Plant Biol. 2003;54:519-46. https://doi.org/10.1146/annurev.arplant.54.031902. 134938.

23. Ralph J, Lapierre C, Boerjan W. Lignin structure and its engineering. Food Biotechnol Plant Biotechnol. 2019;56:240-9. https://doi.org/10.1016/j. copbio.2019.02.019

24. Weng J-K, Chapple C. The origin and evolution of lignin biosynthesis: Tansley review. New Phytol. 2010;187:273-85. https://doi.org/10.1111/j. 1469-8137.2010.03327.x.

25. Kuo J. Morphology, anatomy and histochemistry of the Australian seagrasses of the genus Posidonia KöNIG (Posidoniaceae). I. Leaf blade and leaf sheath of Posidonia australis Hook F. Aquat Bot. 1978;5:171-90. https://doi.org/10.1016/0304-3770(78)90060-8.

26. Kuo J. The nacreous walls of sieve elements in seagrasses. Am J Bot. 1983;70:159. https://doi.org/10.1002/j.1537-2197.1983.tb07854.x.

27. Kuo J, Cambridge ML, Kirkman H. Anatomy and structure of australian seagrasses. In: Larkum AWD, Kendrick GA, Ralph PJ, editors. Seagrasses of Australia. Cham: Springer International Publishing; 2018. p. 93-125. https://doi.org/10.1007/978-3-319-71354-0_4

28. Cambridge ML, Kuo J. Morphology, Anatomy and histochemistry of the Australian seagrasses of the genus Posidonia KöNIG (Posidoniaceae) III. 
Posidonia sinuosa CAmbridge \& Kuo. Aquat Bot. 1982;14:1-14. https://doi. org/10.1016/0304-3770(82)90082-1.

29. Klap V, Hemminga M, Boon J. Retention of lignin in seagrasses: Angiosperms that returned to the sea. Mar Ecol Prog Ser. 2000;194:1-11. https://doi.org/10.3354/meps194001.

30. Sluiter JB, Ruiz RO, Scarlata CJ, Sluiter AD, Templeton DW. Compositional analysis of lignocellulosic feedstocks. 1. Review and description of methods. J Agric Food Chem. 2010;58:9043-53. https://doi.org/10.1021/ff100 8023.

31. Opsahl S, Benner R. Decomposition of senescent blades of the seagrass Halodule wrightii in a subtropical lagoon. Mar Ecol Prog Ser. 1993;94:191205. https://doi.org/10.3354/MEPS094191.

32. Ncibi MC, Jeanne-Rose V, Mahjoub B, Jean-Marius C, Lambert J, Ehrhardt $\mathrm{J}$, et al. Preparation and characterisation of raw chars and physically activated carbons derived from marine Posidonia oceanica $(L)$ fibres. $J$ Hazard Mater. 2009;165:240-9. https://doi.org/10.1016/j.jhazmat.2008.09. 126.

33. Kaal J, Serrano O, Nierop KGJ, Schellekens J, Martínez Cortizas A, Mateo M-Á. Molecular Composition of plant parts and sediment organic matter in a Mediterranean seagrass (Posidonia oceanica) Mat. Aquat Bot. 2016;133:50-61. https://doi.org/10.1016/j.aquabot.2016.05.009.

34. van Erven G, de Visser R, Merkx DWH, Strolenberg W, de Gijsel P, Gruppen $\mathrm{H}$, et al. Quantification of lignin and its structural features in plant biomass using ${ }^{13} \mathrm{C}$ lignin as internal standard for pyrolysis-GC-SIM-MS. Anal Chem. 2017;89:10907-16. https://doi.org/10.1021/acs.analchem.7b02632.

35. van Erven G, de Visser R, de Waard P, van Berkel WJH, Kabel MA. Uniformly ${ }^{13} \mathrm{C}$ Labeled lignin internal standards for quantitative pyrolysis-GC-MS analysis of grass and wood. ACS Sustain Chem Eng. 2019;7:20070-6. https://doi.org/10.1021/acssuschemeng.9b05926.

36. Kaal J, Serrano O, del Río JC, Rencoret J. Radically different lignin composition in Posidonia species may link to differences in organic carbon sequestration capacity. Org Geochem. 2018;124:247-56. https://doi.org/ 10.1016/j.orggeochem.2018.07.017.

37. Rencoret J, Marques G, Serrano O, Kaal J, Martínez AT, del Río JC, et al. Deciphering the unique structure and acylation pattern of Posidonia oceanica lignin. ACS Sustain Chem Eng. 2020;8:12521-33. https://doi.org/ 10.1021/acssuschemeng.0c03502.

38. Raimundo SC, Avci U, Hopper C, Pattathil S, Hahn MG, Popper ZA. Immunolocalization of cell wall carbohydrate epitopes in seaweeds: Presence of land plant epitopes in Fucus vesiculosus L. (Phaeophyceae). Planta. 2016;243:337-54. https://doi.org/10.1007/s00425-015-2412-3.

39. O'Rourke C, Gregson T, Murray L, Sandler IH, Fry SC. Sugar composition of the pectic polysaccharides of charophytes, the closest algal relatives of land-plants: Presence of 3-O-methyl-D-galactose residues. Ann Bot. 2015;116:225-36. https://doi.org/10.1093/aob/mcv089.

40. Mitra PP, Loqué D. Histochemical staining of Arabidopsis thaliana secondary cell wall elements. J Vis Exp. 2014. https://doi.org/10.3791/51381.

41. liyama K, Pant R. The mechanism of the Mäule colour reaction: Introduction of methylated syringyl nuclei into softwood lignin. Wood Sci Technol. 1988;22:167-75. https://doi.org/10.1007/BF00355852.

42. Sibout R, Eudes A, Mouille G, Pollet B, Lapierre C, Jouanin L, et al. CINNAMYL ALCOHOL DEHYDROGENASE-C and -D: Are the primary genes involved in lignin biosynthesis in the floral stem of Arabidopsis. Plant Cell. 2005;17:2059-76. https://doi.org/10.1105/tpc.105.030767.

43. Vazquez-Cooz l, Meyer RW. A differential staining method to identify lignified and unlignified tissues. Biotech Histochem. 2009;77:277-82. https://doi.org/10.1080/bih.77.5-6.277.282.

44. Ralph J, Hatfield RD. Pyrolysis-GC-MS characterization of forage materials. J Agric Food Chem. 1991;39:1426-37. https://doi.org/10.1021/jf000 08a014.

45. Del Río JC, Rencoret J, Prinsen P, Martínez ÁT, Ralph J, Gutiérrez A. Structural Characterization of wheat straw lignin as revealed by analytical pyrolysis, 2D-NMR, and reductive cleavage methods. J Agric Food Chem. 2012;60:5922-35. https://doi.org/10.1021/jł301002n.

46. van Erven G, Hilgers R, de Waard P, Gladbeek E-J, van Berkel WJH, Kabel MA. Elucidation of In Situ ligninolysis mechanisms of the selective white-rot fungus Ceriporiopsis subvermispora. ACS Sustain Chem Eng. 2019;7:16757-64. https://doi.org/10.1021/acssuschemeng.9b04235.

47. Pettitt JM. Reproduction in seagrasses: Nature of the pollen and receptive surface of the stigma in the Hydrocharitaceae. Ann Bot. 1980;45:257-71. https://doi.org/10.1093/oxfordjournals.aob.a085822.
48. Pfeifer L, Shafee T, Johnson KL, Bacic A, Classen B. Arabinogalactanproteins of Zostera marina $L$ contain unique glycan structures and provide insight into adaption processes to saline environments. Sci Rep. 2020;10:8232. https://doi.org/10.1038/s41598-020-65135-5.

49. Mohnen D. Pectin structure and biosynthesis. Curr Opin Plant Biol. 2008;11:266-77. https://doi.org/10.1016/j.pbi.2008.03.006.

50. Atmodjo MA, Hao Z, Mohnen D. Evolving views of pectin biosynthesis. Annu Rev Plant Biol. 2013;64:747-79. https://doi.org/10.1146/annurevarplant-042811-105534.

51. Ovodov YUS, Ovodova RG, Bondarenko OD, Krasikova IN. The pectic substances of Zosteraceae: Part IV. Pectinase digestion of Zosterine. Carbohydr Res. 1971;18:311-8. https://doi.org/10.1016/S0008-6215\%2800\% 2980355-9.

52. Gloaguen V, Brudieux V, Closs B, Barbat A, Krausz P, Sainte-Catherine O, et al. Structural characterization and cytotoxic properties of an apioserich pectic polysaccharide obtained from the cell wall of the marine phanerogam Zostera marina. J Nat Prod. 2010;73:1087-92. https://doi. org/10.1021/np100092c.

53. Avci U, Peña MJ, O’Neill MA. Changes in the abundance of cell wall apiogalacturonan and xylogalacturonan and conservation of rhamnogalacturonan II structure during the diversification of the Lemnoideae. Planta. 2018;247:953-71. https://doi.org/10.1007/s00425-017-2837-y.

54. Sowinski EE, Gilbert S, Lam E, Carpita NC. Linkage structure of cell-wall polysaccharides from three duckweed species. Carbohydr Polym. 2019;223: 115119. https://doi.org/10.1016/j.carbpol.2019.115119.

55. Miroshnikov V. Zostera as an industrial raw material. Zh Prikl Khim. 1940;13:1477-89.

56. Ovodov YUS, Mikheyskaya LV, Ovodova RG, Krasikova IN. The pectic substances of Zosteraceae: Part V. Smith degradation of Zosterine Carbohydr Res. 1971;18:319-22. https://doi.org/10.1016/s0008-6215(00)80356-0.

57. Bell D, Isherwood F, Hardwick NE. D(+)-apiose from the monocotyledon Posidonia australis. J Chem Soc Resumed. 1954;:3702-6. https://doi.org/ 10.1039/JR9540003702

58. Webster J, Stone BA. Isolation, structure and monosaccharide composition of the walls of vegetative parts of Heterozostera tasmanica (MARTENS eX ASCHERS.) den Hartog. Aquat Bot. 1994;47:39-52. https://doi.org/10.1016/ 0304-3770(94)90046-9.

59. Voragen AGJ, Coenen G-J, Verhoef RP, Schols HA. Pectin, a versatile polysaccharide present in plant cell walls. Struct Chem. 2009;20:263-75. https://doi.org/10.1007/s11224-009-9442-z.

60. Matoh T, Kawaguchi S, Kobayashi M. Ubiquity of a borate-rhamnogalacturonan II complex in the cell walls of higher plants. Plant Cell Physiol. 1996;37:636-40. https://doi.org/10.1093/oxfordjournals.pcp.a028992.

61. Wefers D, Bunzel M. NMR Spectroscopic profiling of arabinan and galactan structural elements. J Agric Food Chem. 2016;64:9559-68. https://doi.org/10.1021/acs.jafc.6b04232.

62. Ackerman JD. Sexual reproduction of seagrasses: Pollination in the marine context. In: Larkum A, Orth RJ, Duarte CM, editors. Seagrasses: Biology, ecology and conservation. Dordrecht: Springer, Netherlands; 2006. p. 89-109. https://doi.org/10.1007/978-1-4020-2983-7_4.

63. Peña MJ, Kulkarni AR, Backe J, Boyd M, O'Neill MA, York WS. Structural diversity of xylans in the cell walls of monocots. Planta. 2016;244:589-606. https://doi.org/10.1007/s00425-016-2527-1.

64. Hatfield RD, Rancour DM, Marita JM. Grass Cell Walls: A story of crosslinking. Front Plant Sci. 2017;7:2056. https://doi.org/10.3389/fpls.2016. 02056.

65. Tryfona T, Sorieul M, Feijao C, Stott K, Rubtsov DV, Anders N, et al. Development of an oligosaccharide library to characterise the structural variation in glucuronoarabinoxylan in the cell walls of vegetative tissues in grasses. Biotechnol Biofuels. 2019;12:109. https://doi.org/10.1186/ s13068-019-1451-6.

66. Baydoun EAH, Brett CT. Comparison of cell wall compositions of the rhizomes of three seagrasses. Aquat Bot. 1985;23:191-6. https://doi.org/ 10.1016/0304-3770(89)90106-X.

67. Brennan M, Harris PJ. Distribution of fucosylated xyloglucans among the walls of different cell types in monocotyledons determined by immunofluorescence microscopy. Mol Plant. 2011;4:144-56. https://doi.org/10. 1093/mp/ssq067.

68. Touchette BW, Burkholder JM. Overview of the physiological ecology of carbon metabolism in seagrasses. J Exp Mar Biol Ecol. 2000;250:169-205. https://doi.org/10.1016/S0022-0981(00)00196-9. 
69. Peralta G, Pérez-Lloréns JL, Hernández I, Vergara JJ. Effects of light availability on growth, architecture and nutrient content of the seagrass Zostera noltii HORnem. J Exp Mar Biol Ecol. 2002;269:9-26. https://doi.org/ 10.1016/S0022-0981(01)00393-8.

70. Heglmeier A, Zidorn C. Secondary metabolites of Posidonia oceanica (Posidoniaceae). Biochem Syst Ecol. 2010;38:964-70. https://doi.org/10. 1016/j.bse.2010.07.001.

71. Liu Q, Luo L, Zheng L. Lignins: Biosynthesis and biological functions in plants. Int J Mol Sci. 2018:19:335. https://doi.org/10.3390/ijms19020335.

72. Moura JCMS, Bonine CAV, de Oliveira Fernandes Viana J, Dornelas MC, Mazzafera P. Abiotic and biotic stresses and changes in the lignin content and composition in plants. J Integr Plant Biol. 2010;52:360-76. https://doi. org/10.1111/j.1744-7909.2010.00892.x.

73. Hyde KD, Jones EBG, Leaño E, Pointing SB, Poonyth AD, Vrijmoed LLP. Role of fungi in marine ecosystems. Biodivers Conserv. 1998;7:1147-61. https://doi.org/10.1023/A:1008823515157.

74. Vanholme R, Morreel K, Ralph J, Boerjan W. Lignin engineering. Curr Opin Plant Biol. 2008;11:278-85. https://doi.org/10.1016/j.pbi.2008.03.005.

75. Deniaud-Bouët E, Hardouin K, Potin P, Kloareg B, Hervé C. A review about brown algal cell walls and fucose-containing sulfated polysaccharides: Cell wall context, biomedical properties and key research challenges. Carbohydr Polym. 2017;175:395-408. https://doi.org/10.1016/j.carbpol. 2017.07.082.

76. Ciancia M, Fernández PV, Leliaert F. Diversity of sulfated polysaccharides from cell walls of coenocytic green algae and their structural relationships in view of green algal evolution. Front Plant Sci. 2020;1 1: 554585. https://doi.org/10.3389/fpls.2020.554585.

77. Sabry DA, Cordeiro SL, Ferreira Silva CH, Cunha Farias EH, Sassaki GL, Nader HB, et al. Pharmacological prospection and structural characterization of two purified sulfated and pyruvylated homogalactans from green algae Codium isthmocladum. Carbohydr Polym. 2019;222: 115010. https://doi.org/10.1016/j.carbpol.2019.115010.

78. Aquino RS, Grativol C, Mourão PAS. Rising from the sea: Correlations between sulfated polysaccharides and salinity in plants. PLOS ONE. 2011;6: e18862. https://doi.org/10.1371/journal.pone.0018862.

79. Lamport DTA, Kieliszewski MJ, Showalter AM. Salt stress upregulates periplasmic arabinogalactan proteins: Using salt stress to analyse AGP function. New Phytol. 2006;169:479-92. https://doi.org/10.1111/j.14698137.2005.01591.x.

80. Lahaye PA, Epstein E. Salt toleration by plants: Enhancement with calcium. Science. 1969;166:395-6. https://doi.org/10.1126/science.166.3903. 395.

81. LVX, Yu P, Deng W, Li Y. Transcriptomic analysis reveals the molecular adaptation to $\mathrm{NaCl}$ stress in Zostera marina L. Plant Physiol Biochem. 2018;130:61-8. https://doi.org/10.1016/j.plaphy.2018.06.022.

82. Moore JP, Nguema-Ona EE, Vicré-Gibouin M, Sørensen I, Willats WGT, Driouich $\mathrm{A}$, et al. Arabinose-rich polymers as an evolutionary strategy to plasticize resurrection plant cell walls against desiccation. Planta. 2013;237:739-54. https://doi.org/10.1007/s00425-012-1785-9.

83. Corrêa-Ferreira ML, Viudes EB, de Magalhães PM, de Santana FilhoPaixão A, Sassaki GL, Pacheco AC, et al. Changes in the composition and structure of cell wall polysaccharides from Artemisia annua in response to salt stress. Carbohydr Res. 2019;483:107753. https://doi.org/10.1016/j.carres. 2019.107753.

84. Zhao C, Zayed O, Zeng F, Liu C, Zhang L, Zhu P, et al. Arabinose biosynthesis is critical for salt stress tolerance in Arabidopsis. New Phytol. 2019;224:274-90. https://doi.org/10.1111/nph.15867.

85. Khotimchenko Y, Khozhaenko E, Kovalev V, Khotimchenko M. Cerium binding activity of pectins isolated from the seagrasses Zostera marina and Phyllospadix iwatensis. Mar Drugs. 2012;10:834-48. https://doi.org/ 10.3390/md10040834.

86. Larkum AWD, Waycott M, Conran JG. Evolution and biogeography of seagrasses. In: Larkum AWD, Kendrick GA, Ralph PJ, editors. Seagrasses of Australia. Cham: Springer International Publishing; 2018. p. 3-29. https:// doi.org/10.1007/978-3-319-71354-0_1.

87. den Hartog CKJ. The sea-grasses of the world. Amsterdam: North-Holland Publishing Company; 1970.

88. Aires T, Marbà N, Cunha RL, Kendrick GA, Walker DI, Serrão EA, et al. Evolutionary history of the seagrass genus Posidonia. Mar Ecol Prog Ser. 2011:421:117-30. https://doi.org/10.3354/meps08879.
89. Coyer JA, Hoarau G, Kuo J, Tronholm A, Veldsink J, Olsen JL. Phylogeny and temporal divergence of the seagrass family Zosteraceae using one nuclear and three chloroplast loci. Syst Biodivers. 2013;11:271-84. https:// doi.org/10.1080/14772000.2013.821187.

90. Pagliuso D, Grandis A, Lam E, Buckeridge MS. High saccharification, low lignin, and high sustainability potential make duckweeds adequate as bioenergy feedstocks. BioEnergy Res. 2020. https://doi.org/10.1007/ s12155-020-10211-X.

91. Pfeifer L, Utermöhlen J, Happ K, Permann C, Holzinger A, von Schwartzenberg K, Classen B. Search for evolutionary roots of land plant arabinogalactan-proteins in charophytes: Presence of a rhamnogalactan-protein in Spirogyra pratensis (Zygnematophyceae). Plant J. 2021. https://doi.org/ 10.1111/tpj.15577.

92. Blakeney AB, Harris PJ, Henry RJ, Stone BA. A simple and rapid preparation of alditol acetates for monosaccharide analysis. Carbohydr Res. 1983;113:291-9. https://doi.org/10.1016/0008-6215(83)88244-5.

93. Tang Y, Horikoshi M, Li W. ggfortify: Unified interface to visualize statistical results of popular R packages. R J. 2016;8:474-85. https://doi.org/10. 32614/RJ-2016-060

94. Blumenkrantz N, Asboe-Hansen G. New method for quantitative determination of uronic acids. Anal Biochem. 1973;54:484-9. https://doi.org/10. 1016/0003-2697(73)90377-1.

95. Gerlach D. Botanische Mikrotechnik: Eine Einführung. 2nd edition, revised. Stuttgart: Thieme; 1977.

\section{Publisher's Note}

Springer Nature remains neutral with regard to jurisdictional claims in published maps and institutional affiliations.

Ready to submit your research? Choose BMC and benefit from:

- fast, convenient online submission

- thorough peer review by experienced researchers in your field

- rapid publication on acceptance

- support for research data, including large and complex data types

- gold Open Access which fosters wider collaboration and increased citations

- maximum visibility for your research: over $100 \mathrm{M}$ website views per year

At BMC, research is always in progress.

Learn more biomedcentral.com/submissions 